\title{
Air Pollution and Cognitive Impairment across the Life Course in Humans: A Systematic Review with Specific Focus on Income Level of Study Area
}

\author{
Mina Chandra ${ }^{1, *(D)}$, Chandra Bhushan Rai ${ }^{1}$, Neelam Kumari ${ }^{1}$, Vipindeep Kaur Sandhu ${ }^{1}$ (D), Kalpana Chandra ${ }^{2}$, \\ Murali Krishna ${ }^{3}$, Sri Harsha Kota ${ }^{4}$, Kuljeet Singh Anand ${ }^{5}$ and Anna Oudin ${ }^{6,7}$
}

check for updates

Citation: Chandra, M.; Rai, C.B.; Kumari, N.; Sandhu, V.K.; Chandra, K.; Krishna, M.; Kota, S.H.; Anand, K.S.; Oudin, A. Air Pollution and Cognitive Impairment across the Life Course in Humans: A Systematic Review with Specific Focus on Income Level of Study Area. Int. J. Environ. Res. Public Health 2022, 19, 1405. https://doi.org/10.3390/ ijerph19031405

Academic Editors: Palestini Paola and Paul B. Tchounwou

Received: 13 October 2021 Accepted: 25 December 2021 Published: 27 January 2022

Publisher's Note: MDPI stays neutral with regard to jurisdictional claims in published maps and institutional affiliations.

Copyright: (C) 2022 by the authors. Licensee MDPI, Basel, Switzerland. This article is an open access article distributed under the terms and conditions of the Creative Commons Attribution (CC BY) license (https:// creativecommons.org/licenses/by/ $4.0 /)$.
1 Department of Psychiatry, Centre of Excellence in Mental Health, Atal Bihari Vajpayee Institute of Medical Sciences (formerly PGIMER) and Dr. Ram Manohar Lohia Hospital, New Delhi 110001, India; chandra.b.rai@outlook.com (C.B.R.); kneelam1792@gmail.com (N.K.); sandhu.vipindeep@gmail.com (V.K.S.)

2 Delhi Jal Board, Government of National Capital Territory of Delhi, New Delhi 110094, India; drkalpanachandra@gmail.com

3 JSS Academy of Higher Education \& Research, Mysore 570015, Karnataka, India; muralidoc@gmail.com

4 Department of Civil Engineering, Indian Institute of Technology Delhi, New Delhi 110016, India; harshakota@civil.iitd.ac.in

5 Department of Neurology, Atal Bihari Vajpayee Institute of Medical Sciences (Formerly PGIMER) and Dr. Ram Manohar Lohia Hospital, New Delhi 110001, India; kuljeet_anand@rediffmail.com

6 Department of Public Health and Clinical Medicine, Umeå University, 90187 Umea, Sweden; anna.oudin@med.lu.se

7 Department of Laboratory Medicine, Lund University, 90187 Umea, Sweden

* Correspondence: minasaxena@gmail.com; Tel.: +91-98-1183-1902

\begin{abstract}
Cognitive function is a crucial determinant of human capital. The Lancet Commission (2020) has recognized air pollution as a risk factor for dementia. However, the scientific evidence on the impact of air pollution on cognitive outcomes across the life course and across different income settings, with varying levels of air pollution, needs further exploration. A systematic review was conducted, using Preferred Reporting Items for Systematic reviews and Meta-Analyses (PRISMA) Guidelines to assess the association between air pollution and cognitive outcomes across the life course with a plan to analyze findings as per the income status of the study population. The PubMed search included keywords related to cognition and to pollution (in their titles) to identify studies on human participants published in English until 10 July 2020. The search yielded 84 relevant studies that described associations between exposure to air pollutants and an increased risk of lower cognitive function among children and adolescents, cognitive impairment and decline among adults, and dementia among older adults with supportive evidence of neuroimaging and inflammatory biomarkers. No study from low- and middle-income countries (LMICs)was identified despite high levels of air pollutants and high rates of dementia. To conclude, air pollution may impair cognitive function across the life-course, but a paucity of studies from reLMICs is a major lacuna in research.
\end{abstract}

Keywords: air pollution; particulate matter $2.5\left(\mathrm{PM}_{2.5}\right)$; $\mathrm{PAH}$; global pollution; health effects/risks; cognition; cognitive impairment; dementia

\section{Introduction}

Ambient air pollution is a leading cause of the global disease burden according to the Global Burden of Diseases, Injuries, and Risk Factors Study 2015, especially in low-income and middle-income countries [1]. Recent estimates ascribe 8.9 million deaths per year to ambient particulate matter (PM) having a diameter less than 2.5 microns (PM2.5) [2]. The PM2.5 from fossil fuels alone were, in another study, estimated to be a contributing cause to 10.2 million global excess deaths in 2012, with $62 \%$ of deaths in China (3.9 million) and India (2.5 million) [3]. Western Pacific and South-East Asia have the largest burden of 
disease related to air pollution worldwide, contributed by heavy industry and air pollution hotspots in the developing nations therein [4]. However, lower-middle income countries (LMICs) as well as low-income countries (LICs) have often been left behind when it comes to conducting epidemiological studies on air pollution health effects [5,6]. Unfortunately, it is not certain that results from epidemiological studies in high-income countries (HICs) or upper-middle-income countries (UMICs) can be directly extrapolated to LMICs or LICs, because both the quantities and sources of air pollution often differ between HICs/HMICs and LMICs/LICs, making the chemical composition of exposure, and subsequent health effects, unique. For example, in India (an LMIC), pollution is worse than in China (a UMIC). There are 22 Indian cities on the global list of the 30 most polluted cities. Apart from urban sources of air pollution, the burning of agricultural stubble in nearby rural areas also contributes to the burden of air pollution in Indian cities. In addition, in India all indicators of air pollution greatly exceed WHO standards [7], and concentrations are increasing [8]. Furthermore, African PM emissions often originate from old diesel-powered vehicles, and poor household waste management, and households burning biomass are the predominant contributors to outdoor air pollution [9]. In order to reduce uncertainties in the estimates for LICs and LMICs, epidemiological studies in these countries are, thus, needed [6].

Cognitive function, a prominent determinant of human capital, health, and socioeconomic status, is impacted by cumulative biological, social, and environmental exposures across the life course. Cognitive disorders such as dementia entail great suffering and high societal costs, and the prevalence worldwide is increasing. The number of people living with dementia is 55 million and is estimated to reach 75 million worldwide by 2030, with the majority living in LMICs and LICs. Recent studies have reported a decline in the prevalence of dementia in high-income countries, suggesting that dementia may, at least partially, be preventable $[10,11]$.

Emerging studies suggest that exposure to air pollution may be associated with cognitive impairment, with reported effects ranging from impaired neurocognitive development in infancy and childhood to higher rates of cognitive decline and dementia in later life [12-17]. The Lancet Commission (2020) has recognized air pollution as a risk factor for dementia [18].

The aim and objective of this paper is to systematically review the evidence base with respect to the relationship between air pollution and cognitive health outcomes including dementia across the life course and in diverse income settings. There is a special focus on income level of the country of the study areas since LICs and LMICs often previously have been left behind when it comes to epidemiological studies of air pollution health effects. The high burden of cognitive disorders in LICs and LMICs, combined with the high burden of disease due to air pollution in these countries, highlights the need to make an inventory of epidemiological studies on air pollution in association with cognitive disorders in these countries. The contextualizing of research findings in terms of income settings of the research studies is valuable as the countries with lower income levels are disproportionately affected by air pollution while being resource-constrained to address either air pollution or its health impact.

\section{Materials and Methods}

A systematic review was conducted to answer the research question on the impact of air pollution on cognitive health across the life course.

The review took place between January and October 2020 based on the Preferred Reporting Items for Systematic reviews and Meta-Analyses (PRISMA) [19] Statement using a defined protocol that is unpublished (Appendix A).

\subsection{Search Strategy}

A systematic search of the PubMed database was performed using PRISMA Guidelines with no time limit on the date of publication [19]. The Population, Investigated Exposure, Comparison, Outcome (PICO) Framework for this review is given in Table 1. 
Table 1. The Population, Investigated Exposure, Comparison, Outcome (PICO) Framework for Research Question.

\begin{tabular}{|c|c|}
\hline Population & $\begin{array}{c}\text { Any Age Group } \\
\text { Both Genders } \\
\text { Participant Level Data or Cohort Level Data }\end{array}$ \\
\hline Investigated exposure & $\begin{array}{l}\text { Air Pollution: single or multiple } \\
\text { Cross sectional or Cumulative exposure } \\
\text { In utero exposure, Circumscribed cross } \\
\text { sectional exposure or Lifetime exposure }\end{array}$ \\
\hline Comparison & $\begin{array}{c}\text { Air Pollutant exposed population comparators } \\
\text { Gender comparators } \\
\text { Income settings comparators }\end{array}$ \\
\hline Outcome & $\begin{array}{c}\text { Cognition and its different domains, } \\
\text { neuroimaging markers }\end{array}$ \\
\hline
\end{tabular}

The search string included keywords related to cognition and air pollution. Studies having any of the following keywords related to air pollution (exposure variable) and cognition (outcome variable) in their titles were identified. The keywords related to pollution utilized for PubMed search were Air Pollution, Pollutant (s), Particulate Matter, PM, Haze, Smog, Traffic-related air pollution (TRAP) and apportionment. The key words related to cognition utilized for PubMed search were Dementia, Cognitive, Memory, Attention, Cognition, Concentration, Orientation, Alertness, Alert, Intelligence, Emotion (s), Language, Reasoning, Planning, Decision making, Judgement, Recall, Learning, Emotion, Insight, Processing, Visuoconstructional, Coordination and Perception.

\subsection{Selection Criteria}

The inclusion criteria for the studies were full-text articles published in English with no time limit on date of publication, including original studies, systematic reviews and meta-analysis from any country on human participants of any age or gender. Protocols, letters to the editor and grey literature were excluded.

Following the definition of the World Bank, country-level income was determined by a nation's gross national income (GNI) per capita, where HICs, UMICs, LMICs and LICs had GNIs of USD > 12,375, 3996-12,375, 1026-3995, and <1026 [20], respectively.

\subsection{Screening Strategy}

The search strategy comprised a two-stage process, In the first stage, three reviewers (C.B.R., N.K., V.K.S.) independently screened identified studies for eligibility by screening the titles and abstracts for study inclusion and exclusion criteria. References and citations of included papers were also reviewed to include additional potential articles. Abstracts of conference proceedings were searched for any relevant papers and posters. The second stage comprised independently screening the full texts of studies for eligibility by the three aforesaid reviewers. If the reviewers did not agree, then a more experienced reviewer was consulted (M.C.).

\subsection{Data Extraction and Analysis}

Each included study was examined in detail. Data from the included studies were recorded for publication date, study setting, study type, duration of the study, study population, air pollution exposure and cognitive-outcome measures studied and reported. The results obtained were examined against the income level of the study area as per World Bank classification and contextualized. The extracted data were calibrated for consistency and completeness by independent reviewers (M.C. and K.C.). Due to heterogeneity in exposure and outcome variables and tools employed to assess these parameters, a statistical meta-analysis was not possible. Instead, the evidence was analyzed and presented based 
on nature of air pollutant, age profile, and gender of participants as well as income levels of study areas.

\subsection{Quality Assessment}

The quality of individual studies was evaluated using the Revised tool for Quality Assessment on Diagnostic Accuracy Studies (QUADAS-2) [21]. The QUADAS-2 assesses the quality of primary diagnostic accuracy studies based on four key domains covering patient selection, index test, reference standard, and flow of patients through the study and timing of the index test(s) and reference standard ("flow and timing"). Each domain is evaluated for the risk of bias (using signaling questions), and the first three are also assessed for applicability.

Two senior authors, not involved in the initial screening of studies for inclusion in the systematic review (vide supra), independently evaluated primary studies using QUADAS-2 (M.C., K.C.), and any difference in agreement was resolved by consensus with the third experienced author (M.K.), who was not involved in the initial screening of papers for eligibility criteria or quality evaluation. This ensured objectivity in the systematic review process.

Statistical methods for assessing publication bias using techniques such as funnel plots were considered but ruled out due to the heterogenous nature of available scientific literature on multiple exposures for multiple cognitive and neuroimaging outcomes across different age groups. We did not exclude any study based on quality. The results of analysis of publication bias are given in Table 2 and Figure 1.

Table 2. Analysis of publication bias in published literature on cognitive impact of air pollution using the QUADAS-2 framework.

\begin{tabular}{|c|c|c|c|c|c|c|c|c|}
\hline \multirow{2}{*}{ S. No. } & \multirow{2}{*}{$\begin{array}{l}\text { Study: Author } \\
\text { (Year) }\end{array}$} & \multicolumn{4}{|c|}{$\begin{array}{c}\text { Risk of Bias } \\
\text { Low: } 1 \text {, High: } 2 \text {, Uncertain: } 3\end{array}$} & \multicolumn{3}{|c|}{$\begin{array}{c}\text { Applicability Concerns } \\
\text { Low: 1, High: 2, Uncertain: } 3\end{array}$} \\
\hline & & $\begin{array}{l}\text { Participant } \\
\text { Selection }\end{array}$ & Index Test & $\begin{array}{l}\text { Reference } \\
\text { Standards }\end{array}$ & $\begin{array}{l}\text { Flow and } \\
\text { Timing }\end{array}$ & $\begin{array}{l}\text { Participant } \\
\text { Selection }\end{array}$ & Index Test & $\begin{array}{l}\text { Reference } \\
\text { Standards }\end{array}$ \\
\hline A & \multicolumn{8}{|c|}{ Studies from High Income Settings } \\
\hline 1 & $\begin{array}{l}\text { Lee et al. (2019) } \\
\text { [22] }\end{array}$ & 1 & 1 & 1 & 1 & 1 & 1 & 1 \\
\hline 2 & $\begin{array}{l}\text { Lo et al. (2019) } \\
\text { [23] }\end{array}$ & 1 & 1 & 1 & 1 & 1 & 1 & 1 \\
\hline 3 & $\begin{array}{l}\text { Molina- } \\
\text { Sotomayor et al. } \\
(2019)[24]\end{array}$ & 2 & 1 & 1 & 2 & 1 & 1 & 1 \\
\hline 4 & $\begin{array}{l}\text { Andersson et al. } \\
\text { (2018) [25] }\end{array}$ & 1 & 1 & 1 & 1 & 2 & 1 & 1 \\
\hline 5 & $\begin{array}{l}\text { Berghuis et al. } \\
\text { (2018) [26] }\end{array}$ & 2 & 1 & 1 & 1 & 2 & 1 & 1 \\
\hline 6 & $\begin{array}{l}\text { Carey et al. } \\
(2018)[27]\end{array}$ & 1 & 1 & 1 & 1 & 1 & 1 & 1 \\
\hline 7 & $\begin{array}{l}\text { Cullen et al. } \\
(2018)[28]\end{array}$ & 1 & 1 & 1 & 1 & 1 & 1 & 1 \\
\hline 8 & $\begin{array}{l}\text { Guxens et al. } \\
\text { (2018) [14] }\end{array}$ & 1 & 1 & 1 & 1 & 1 & 1 & 1 \\
\hline 9 & $\begin{array}{l}\text { Kerin et al. (2018) } \\
\text { [29] }\end{array}$ & 2 & 1 & 1 & 1 & 2 & 1 & 1 \\
\hline
\end{tabular}


Table 2. Cont.

\begin{tabular}{|c|c|c|c|c|c|c|c|c|}
\hline \multirow{2}{*}{ S. No. } & \multirow{2}{*}{$\begin{array}{l}\text { Study: Author } \\
\text { (Year) }\end{array}$} & \multicolumn{4}{|c|}{$\begin{array}{c}\text { Risk of Bias } \\
\text { Low: } 1 \text {, High: } 2 \text {, Uncertain: } 3\end{array}$} & \multicolumn{3}{|c|}{$\begin{array}{c}\text { Applicability Concerns } \\
\text { Low: 1, High: } 2 \text {, Uncertain: } 3\end{array}$} \\
\hline & & $\begin{array}{l}\text { Participant } \\
\text { Selection }\end{array}$ & Index Test & $\begin{array}{l}\text { Reference } \\
\text { Standards }\end{array}$ & $\begin{array}{l}\text { Flow and } \\
\text { Timing }\end{array}$ & $\begin{array}{l}\text { Participant } \\
\text { Selection }\end{array}$ & Index Test & $\begin{array}{l}\text { Reference } \\
\text { Standards }\end{array}$ \\
\hline A & \multicolumn{8}{|c|}{ Studies from High Income Settings } \\
\hline 10 & $\begin{array}{l}\text { Oudin et al. } \\
(2018)[30]\end{array}$ & 1 & 1 & 1 & 1 & 1 & 1 & 1 \\
\hline 11 & $\begin{array}{l}\text { Ailshire et al. } \\
\text { (2017) [31] }\end{array}$ & 3 & 1 & 1 & 1 & 2 & 1 & 1 \\
\hline 12 & $\begin{array}{l}\text { Alvarez-Pedrerol } \\
\quad \text { (2017) [12] }\end{array}$ & 1 & 1 & 1 & 1 & 1 & 1 & 1 \\
\hline 13 & $\begin{array}{l}\text { Cacciottolo et al. } \\
\text { (2017) [15] }\end{array}$ & 1 & 1 & 1 & 1 & 1 & 1 & 1 \\
\hline 14 & $\begin{array}{l}\text { Chen et al. (2017) } \\
\text { [32] }\end{array}$ & 1 & 1 & 1 & 1 & 1 & 1 & 1 \\
\hline 15 & $\begin{array}{l}\text { Colicino et al. } \\
\text { (2017) [33] }\end{array}$ & 2 & 1 & 1 & 1 & 2 & 1 & 1 \\
\hline 16 & $\begin{array}{l}\text { Forns et al. (2017) } \\
\text { [34] }\end{array}$ & 1 & 1 & 1 & 1 & 1 & 1 & 1 \\
\hline 17 & $\begin{array}{l}\text { Lett et al. (2017) } \\
\qquad \text { [35] }\end{array}$ & 1 & 1 & 1 & 1 & 1 & 1 & 1 \\
\hline 18 & $\begin{array}{l}\text { Oudin et al. } \\
(2017)[36]\end{array}$ & 1 & 1 & 1 & 1 & 1 & 1 & 1 \\
\hline 19 & $\begin{array}{l}\text { Stingone et al. } \\
\text { (2017) [37] }\end{array}$ & 1 & 1 & 1 & 1 & 1 & 1 & 1 \\
\hline 20 & $\begin{array}{l}\text { Sunyer et al. } \\
(2017)[38]\end{array}$ & 1 & 1 & 1 & 1 & 1 & 1 & 1 \\
\hline 21 & $\begin{array}{l}\text { Tallon et al. } \\
\text { (2017) [39] }\end{array}$ & 1 & 1 & 1 & 1 & 1 & 1 & 1 \\
\hline 22 & $\begin{array}{l}\text { Tzivian et al. } \\
\text { (2017) [40] }\end{array}$ & 1 & 1 & 1 & 1 & 1 & 1 & 1 \\
\hline 23 & $\begin{array}{l}\text { Best et al. (2016) } \\
\text { [41] }\end{array}$ & 1 & 1 & 1 & 1 & 1 & 1 & 1 \\
\hline 24 & $\begin{array}{l}\text { Oudin et al. } \\
(2016)[42]\end{array}$ & 1 & 1 & 1 & 1 & 1 & 1 & 1 \\
\hline 25 & $\begin{array}{l}\text { Porta et al. (2016) } \\
\text { [43] }\end{array}$ & 3 & 1 & 1 & 1 & 3 & 1 & 1 \\
\hline 26 & $\begin{array}{l}\text { Tzivian et al. } \\
\text { (2016) [44] }\end{array}$ & 1 & 1 & 1 & 1 & 1 & 1 & 1 \\
\hline 27 & $\begin{array}{l}\text { Tzivian et al. } \\
\text { (2016) [45] }\end{array}$ & 1 & 1 & 1 & 1 & 1 & 1 & 1 \\
\hline 28 & $\begin{array}{l}\text { Chen et al. (2015) } \\
\text { [46] }\end{array}$ & 1 & 1 & 1 & 1 & 1 & 1 & 1 \\
\hline 29 & $\begin{array}{l}\text { Harris et al. } \\
\text { (2015) [46] }\end{array}$ & 1 & 1 & 1 & 1 & 1 & 1 & 1 \\
\hline 30 & $\begin{array}{l}\text { Peterson et al. } \\
\text { (2015) [47] }\end{array}$ & 1 & 1 & 1 & 1 & 1 & 1 & 1 \\
\hline 31 & $\begin{array}{l}\text { Schikowski et al. } \\
\text { (2015) [48] }\end{array}$ & 1 & 1 & 1 & 1 & 1 & 1 & 1 \\
\hline 32 & $\begin{array}{l}\text { Sunyer et al. } \\
\text { (2015) [49] }\end{array}$ & 1 & 1 & 1 & 1 & 1 & 1 & 1 \\
\hline 33 & $\begin{array}{c}\text { Ailshire and } \\
\text { Clarke (2014) [50] }\end{array}$ & 3 & 1 & 1 & 3 & 2 & 1 & 1 \\
\hline
\end{tabular}


Table 2. Cont.

\begin{tabular}{|c|c|c|c|c|c|c|c|c|}
\hline \multirow{2}{*}{ S. No. } & \multirow{2}{*}{$\begin{array}{l}\text { Study: Author } \\
\text { (Year) }\end{array}$} & \multicolumn{4}{|c|}{$\begin{array}{c}\text { Risk of Bias } \\
\text { Low: 1, High: } 2 \text {, Uncertain: } 3\end{array}$} & \multicolumn{3}{|c|}{$\begin{array}{c}\text { Applicability Concerns } \\
\text { Low: 1, High: 2, Uncertain: } 3\end{array}$} \\
\hline & & $\begin{array}{l}\text { Participant } \\
\text { Selection }\end{array}$ & Index Test & $\begin{array}{l}\text { Reference } \\
\text { Standards }\end{array}$ & $\begin{array}{l}\text { Flow and } \\
\text { Timing }\end{array}$ & $\begin{array}{l}\text { Participant } \\
\text { Selection }\end{array}$ & Index Test & $\begin{array}{l}\text { Reference } \\
\text { Standards }\end{array}$ \\
\hline 34 & $\begin{array}{c}\text { Ailshire and } \\
\text { Crimmins (2014) } \\
\text { [51] }\end{array}$ & 1 & 1 & 1 & 1 & 1 & 1 & 1 \\
\hline 35 & $\begin{array}{l}\text { Gatto et al. (2014) } \\
\text { [52] }\end{array}$ & 1 & 1 & 1 & 1 & 1 & 1 & 1 \\
\hline 36 & $\begin{array}{l}\text { Guxens et al. } \\
\text { (2014) [53] }\end{array}$ & 1 & 1 & 1 & 1 & 1 & 1 & 1 \\
\hline 37 & $\begin{array}{l}\text { Tonne et al. } \\
(2014)[54]\end{array}$ & 1 & 1 & 1 & 1 & 1 & 1 & 1 \\
\hline 38 & $\begin{array}{l}\text { Loop et al. (2013) } \\
\text { [55] }\end{array}$ & 1 & 1 & 1 & 1 & 1 & 1 & 1 \\
\hline 39 & $\begin{array}{l}\text { Power et al. } \\
(2013)[56]\end{array}$ & 1 & 1 & 1 & 1 & 1 & 1 & 1 \\
\hline 40 & $\begin{array}{l}\text { Weuve et al. } \\
(2012)[57]\end{array}$ & 1 & 1 & 1 & 1 & 1 & 1 & 1 \\
\hline 41 & $\begin{array}{l}\text { Power et al. } \\
\text { (2011) [58] }\end{array}$ & 1 & 1 & 1 & 1 & 1 & 1 & 1 \\
\hline 42 & $\begin{array}{l}\text { Edwards et al. } \\
\text { (2010) [59] }\end{array}$ & 1 & 1 & 1 & 1 & 1 & 1 & 1 \\
\hline 43 & $\begin{array}{l}\text { Freire et al. } \\
(2010)[60]\end{array}$ & 3 & 1 & 1 & 1 & 2 & 1 & 1 \\
\hline 44 & $\begin{array}{c}\text { Chen and } \\
\text { Schwartz (2009) } \\
{[61]}\end{array}$ & 1 & 1 & 1 & 1 & 1 & 1 & 1 \\
\hline 45 & $\begin{array}{l}\text { Perera et al. } \\
(2009) \text { [62] }\end{array}$ & 1 & 1 & 1 & 1 & 1 & 1 & 1 \\
\hline 46 & $\begin{array}{l}\text { Ranft et al. (2009) } \\
\text { [63] }\end{array}$ & 3 & 1 & 1 & 1 & 1 & 1 & 1 \\
\hline 47 & $\begin{array}{l}\text { Lee et al. (2007) } \\
\text { [64] }\end{array}$ & 1 & 1 & 1 & 1 & 1 & 1 & 1 \\
\hline B & \multicolumn{8}{|c|}{ Studies from Upper Middle Income Settings } \\
\hline 1 & $\begin{array}{l}\text { Saenz et al. } \\
(2018)[65]\end{array}$ & 1 & 1 & 1 & 1 & 1 & 1 & 1 \\
\hline 2 & $\begin{array}{l}\text { Zhang et al. } \\
(2018) \text { [66] }\end{array}$ & 1 & 1 & 1 & 1 & 1 & 1 & 1 \\
\hline 3 & $\begin{array}{l}\text { Calderón- } \\
\text { Garcidueñas et al. } \\
\text { (2016) [67] }\end{array}$ & 2 & 1 & 1 & 2 & 3 & 1 & 3 \\
\hline 4 & $\begin{array}{l}\text { Calderón- } \\
\text { Garcidueñas et al. } \\
\text { (2012) [68] }\end{array}$ & 2 & 1 & 1 & 2 & 2 & 1 & 1 \\
\hline 5 & $\begin{array}{l}\text { Calderón- } \\
\text { Garcidueñas et al. } \\
\text { (2011) [69] }\end{array}$ & 2 & 1 & 1 & 2 & 2 & 1 & 2 \\
\hline 6 & $\begin{array}{l}\text { Calderón- } \\
\text { Garcidueñas et al. } \\
\text { (2008) [13] }\end{array}$ & 2 & 1 & 1 & 2 & 2 & 1 & 1 \\
\hline
\end{tabular}




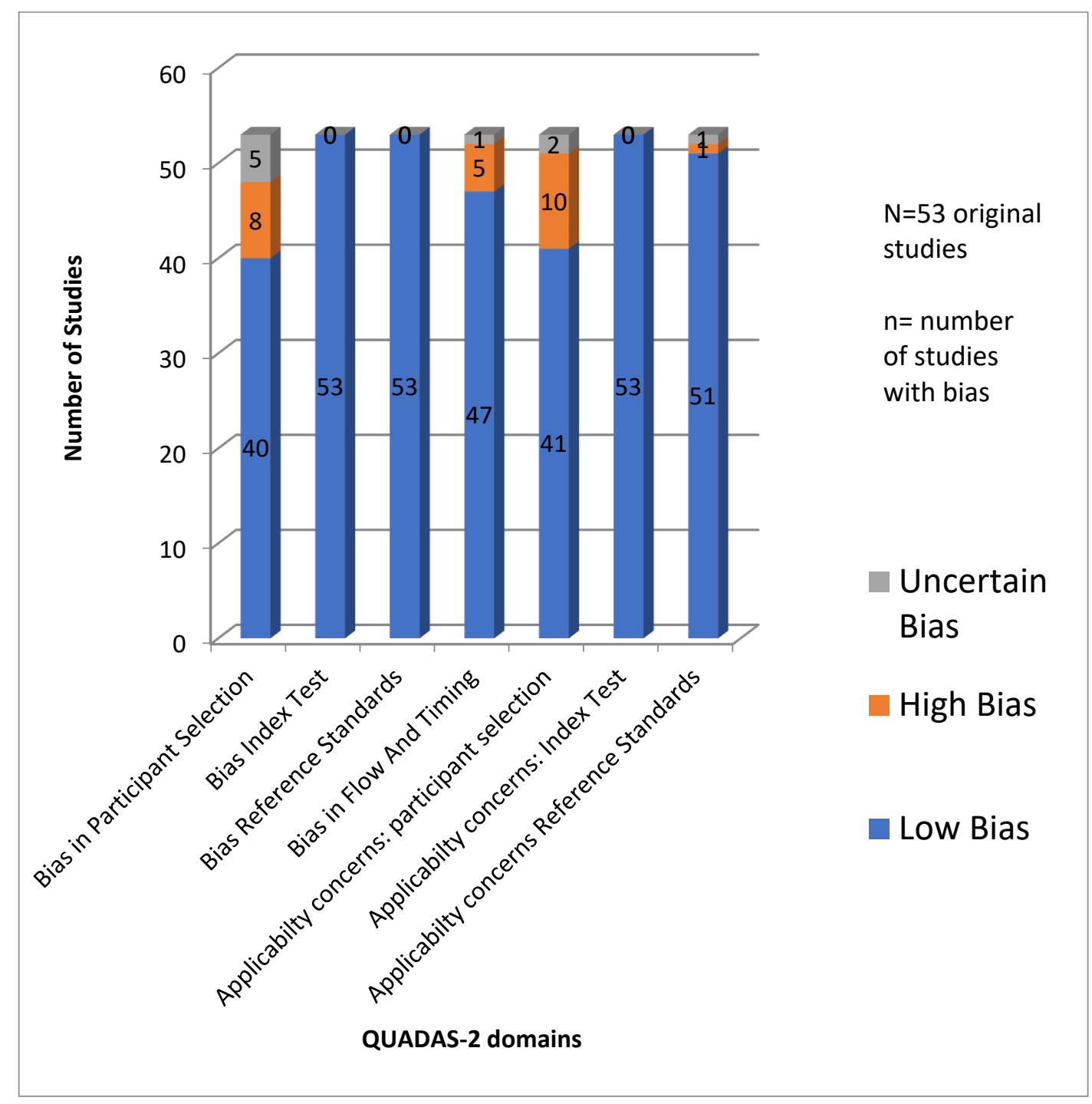

Figure 1. Analysis of publication bias metrics for literature on cognitive impact of air pollution using QUADAS-2.

\section{Results}

\subsection{Original Research Studies Obtained on Screening}

A total of 1173 studies with a keyword related to cognition and a keyword related to pollution (in their titles) were obtained until 10 July 2020. The remaining 350 studies were manually reviewed for relevance (Rai, Sandhu, Kumari) to yield 53 original research studies (Figure 2). 


\section{Identification of studies via databases and registers}

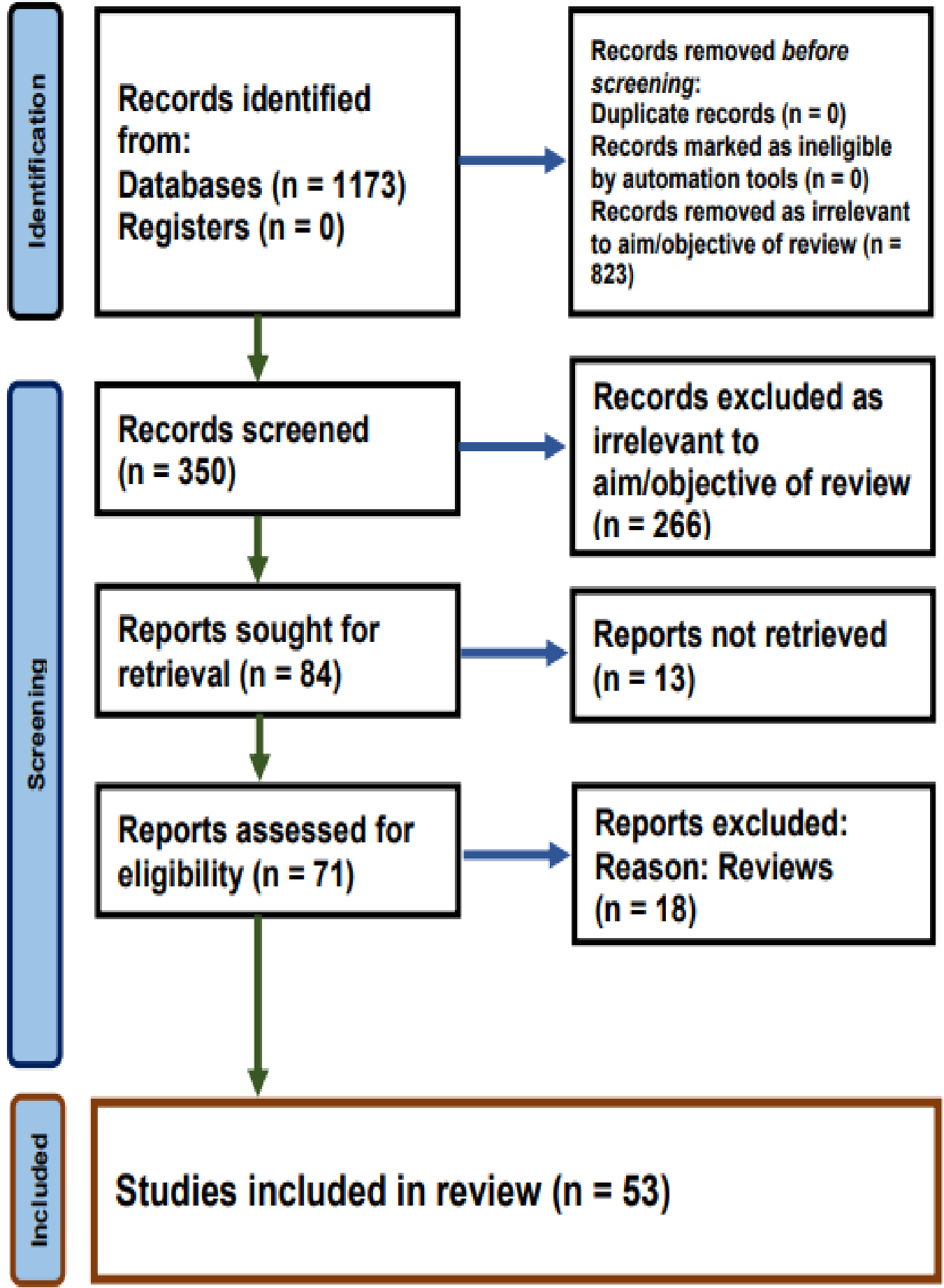

Figure 2. PubMed search results for studies on Air Pollution and Cognition across Life-Course.

3.2. Income Levels of Sites of Original Studies

The 53 original studies included 47 conducted in HICs and 6 conducted in LMICs. These are summarized in Table 3. 
Table 3. Summary of original research on cognitive impact of air pollution across life course.

\begin{tabular}{|c|c|c|c|c|c|c|}
\hline S. No. & Author (Year) & Study Site & Study Population & Exposure Studied & Outcome Variable Studied & Cognitive Impact \\
\hline A & \multicolumn{6}{|c|}{ Studies from High Income Settings } \\
\hline 1 & Lee et al. (2019) [22] & $\begin{array}{l}\text { South-eastern part of } \\
\text { the United States }\end{array}$ & $\begin{array}{l}94 \text { million follow-up records } \\
\text { from fee-for-service Medicare } \\
\text { records for } 13 \text { million Medicare } \\
\text { beneficiaries of fee for service } \\
\text { (FFS) residing in the } \\
\text { southeastern United States } \\
\text { (U.S.) from } 2000 \text { to } 2013 \text {. }\end{array}$ & $\begin{array}{l}\text { Spatially and temporally continuous } \\
\qquad \mathrm{PM}_{2.5} \text { exposure data }\end{array}$ & $\begin{array}{l}\text { Hospitalization rates for } \\
\text { dementia }\end{array}$ & $\begin{array}{c}\text { Long-term exposure to a high } \mathrm{PM}_{2.5} \\
\text { levels associated with increased } \\
\text { hospitalization with dementia per } \\
1 \mu \mathrm{g} / \mathrm{m}^{3} \text { increase in annual } \mathrm{PM}_{2.5} \\
\text { with higher risk for vascular } \\
\text { dementia. } \\
\text { Did not report analysis stratified by } \\
\text { sex }\end{array}$ \\
\hline 3 & $\begin{array}{l}\text { Molina-Sotomayor et al. } \\
\text { (2019) [24] }\end{array}$ & Chile & $\begin{array}{l}181 \text { older women, patients of } \\
\text { the "La Estrella" Health Center } \\
\text { of the Pudahuel commune, } \\
\text { Metropolitan Region of Santiago } \\
\text { de Chile, and patients of the } \\
\text { Senior Centers of Viña del Mar } \\
\text { City-Chile }\end{array}$ & $\begin{array}{c}\text { Average } \\
\mathrm{PM}_{10} \\
\mathrm{PM}_{2.5} \\
\mathrm{NO}_{2} \\
\mathrm{SO}_{2} \\
\text { Ozone } \\
\text { Concentrati-on between 2012-2014 } \\
\text { Cardio-respiratory Aerobic exercise } \\
\text { indicators: } \\
\text { Maximum oxygen uptake }\left(\mathrm{VO}_{2 \mathrm{max}}\right) \text {, } \\
\text { estimated by the Six-Minute Walk } \\
\text { Test (6mWT); heart rate }(\mathrm{HR}) ; \text { and } \\
\text { oxygen saturation }\left(\mathrm{SpO}_{2}\right) \text {. }\end{array}$ & $\begin{array}{l}\text { Mini Mental State Examination } \\
\text { (MMSE) }\end{array}$ & $\begin{array}{l}\text { Significant differences }(p<0.05) \\
\text { between the Active Group residing } \\
\text { in relatively less polluted areas } \\
\text { versus sedentary group residing in } \\
\text { more polluted areas on all the } \\
\text { MMSE dimensions except } \\
\text { "Registration", and in all the } \\
\text { physiological variables }\left(\mathrm{VO}_{2 \max }\right. \\
\left.\mathrm{SpO}_{2}, \mathrm{HR}\right) \text {. } \\
\text { Aerobic exercise may be a protective } \\
\text { factor adverse cognitive effects of air } \\
\text { pollution have on cognition } \\
\text { probably due to improvement in the } \\
\text { mechanisms of oxygen transport. }\end{array}$ \\
\hline 4 & $\begin{array}{c}\text { Andersson et al. (2018) } \\
{[25]}\end{array}$ & Umea, Sweden & $\begin{array}{c}\text { Data of } 1721 \text { participants aged } \\
55-85 \text { years at baseline (Male: } \\
\text { Female = 985:736 of Betula } \\
\text { project, a longitudinal study of } \\
\text { health and ageing aged 55- } 85 \\
\text { years at baseline }\end{array}$ & $\begin{array}{l}\text { Estimates of annual mean levels of } \\
\text { nitrogen oxides }\left(\mathrm{NO}_{\mathrm{x}}\right) \text { at the } \\
\text { participants' residential address } \\
\text { using a land-use regression model. } \\
\text { Modelled data for road traffic noise } \\
\text { levels at the participants' residential } \\
\text { address }\end{array}$ & Dementia incidence & $\begin{array}{c}302 \text { of } 1721 \text { participants at baseline, } \\
302 \text { developed dementia during the } \\
\text { follow up period. Residing in the } \\
\text { two highest quartiles of } \mathrm{NO}_{x} \\
\text { exposure was associated with an } \\
\text { increased risk of dementia which } \\
\text { was not modified by adjusting for } \\
\text { noise. } \\
\text { Did not report analysis stratified by } \\
\text { sex }\end{array}$ \\
\hline
\end{tabular}


Table 3. Cont.

S. No. Author (Year) Study Site Study Population Exposure Studied
Outcome Variable Studied

101 children aged 13-15 years (M:F 55:46) participating in Development at Adolescence and Chemical Exposure (DACE)-study a follow-up of two Dutch birth cohorts.
Maternal pregnancy serum levels o PCB-153 and three $\mathrm{OH}-\mathrm{PCBs}$,

9 PCBs, 5 polybrominated dipheny ethers (PBDEs), dichloroethene (DDE), pentachlorophenol (PCP) and hexabroomcyclododecane (HBCDD) in different parts of the cohort Maternal smoking and alcohol use
Wechsler Intelligence Scale for Children, third edition, Dutch version (WISC-III-NL) Dutch version of the Rey's Auditory Verbal Learning Test (AVLT)

Movement Assessment Battery for Children (Movement-ABC)
Average annual concentrations of $\mathrm{NO}_{2}, \mathrm{PM}_{2.5}$, ozone $\left(\mathrm{O}_{3}\right)$, traffic Carey et al. (2018) [27]

London, UK
Retrospective cohort of 130, adults aged $50-79$ years intensity, distance from major road and night-time noise levels
Clinical diagnosis of Dementia

\section{Cognitive Impac}

Significant association between CB-183 and lower total intelligence HBCDD with lower performance intelligence and PBDEs with lower intelligence and PBDEs with low verbal memory Positive trends
between OH-PCBs and verbal intelligence, and a negative trend between BDE-153 and fine motor skills was observed

Several OH-PCBs associated with more optimal sustained attention and balance

CONTD ON NEXT PAGE

Boys had poorer outcomes on fine motor skills and better outcomes on ball skills with positive trend was seen between 4-OH-PCB-107 and fine motor skills

In girls, Prenatal DDE levels were associated with (sub)clinical motor performance

Positive exposure-response Plationship between dementia and all measures of air pollution excep

Did not report gender based findings

Weak association between air pollutant exposure and cognitive performance at baseline ose-dependent lower reaction time, higher error rate on a

Cognitive function including

Cumulative impact of outdoor air 86,759 middle- to older-aged adults from the UK Biobank

pollution exposure $\left(\mathrm{PM}_{10}, \mathrm{PM}_{2.5}\right.$, $\left.\mathrm{NO}_{2}, \mathrm{NO}_{\mathrm{x}}\right)$ reasoning test, test, reacion time, prospective meme, prospective numeric memory isuospatial memory test and lowe numeric memory scores) with no

such association at 2.8 years follow-up

Did not report analysis stratified by 
Table 3. Cont.

S. No. Author (Year)

Data from population-based birth cohorts-GENERATION (The Netherlands) (2002-2006) that recruited mott dyats including 8879 pregnant

Guxens et al. (2018) [14] Nether-lands

dyads inclu between April 2002 and January 2006 were taken of which 783 children between ages of 6-10 years participated in MRI sub-study
Prenatal exposure to air pollutants such as $\left(\mathrm{NO}_{2}, \mathrm{NO}_{\mathrm{x}}\right)$ in all regions and $\mathrm{PM}\left(\mathrm{PM}_{2.5}, \mathrm{PM}_{10}\right.$ and PM coarse $)$ and $\mathrm{PM}_{25}$ absorbance in a subgroup using land-use regression models for the period 2008 to 2011 and then modelled for air pollutant profile for the exact pregnancy periods using background monitoring sites.
Outcome Variable Studied

MRI Brain

Cognitive and psycho-moto developmen
Mullen Scales of Early Learning

327 children with Autism Spectrum Disorder (ASD) from the Childhood Autism Risks from Genetics and the Environment study
Exposure to $\mathrm{NO}_{2}, \mathrm{PM}_{2.5}$ and $\mathrm{PM}_{10}$ ozone, and near-roadway air pollution in each trimester of pregnancy and first year of life.
(MSEL), the Vineland Adaptive Behavior Scales (VABS), and the Autism Diagnostic Observation Schedule calibrated severity

score.

Cognitive Impact

Air pollution exposure was not associated with global brain volumes

Higher prenatal PM exposure per $5 \mathrm{\mu g} / \mathrm{m}^{3}$ had a dose-dependent thinning of cortex increase in severa brain regions of both hemispheres (e.g., cerebral cortex of the precuneus in Right hemisphere). Reduced cerebral cortex in precuneus and rostral middle frontal regions partially mediated the association between PM exposure and impaired inhibitory control. Did not report analysis stratified by sex

ASD severity not associated with any air pollutant exposure.

Prenatal and First year exposure to

$\mathrm{NO}_{2}$ associated with impaired

cognitive performance, adaptive functioning and behavioral indices but not severity of ASD

3rd Trimester $\mathrm{PM}_{10}$ exposure was

paradoxically associated with improved behavioral perforith Did not report analysis st sex

Increased dose-dependent risk for

1806 participants from Betula project from Umeå, Northern Sweden enrolled between (1993-1995) and followed upto 2010
Modelled levels of source-specific residential fine PM exposure to wood stoves or wood boilers and traffic
Validated data on dementia diagnosis incident dementia (Vascular

Dementia and Alzheimer's Disease) with local residential wood burning and traffic exhaust

Did not report analysis stratified by 
Table 3. Cont.

\begin{tabular}{|c|c|c|c|c|c|c|}
\hline S. No. & Author (Year) & Study Site & Study Population & Exposure Studied & Outcome Variable Studied & Cognitive Impact \\
\hline 11 & $\begin{array}{c}\text { Ailshire et al. (2017) } \\
\text { [31] }\end{array}$ & USA & $\begin{array}{c}779 \text { U.S. adults age } \geq 55 \text { years } \\
\text { from the } 2001 / 2002 \text { wave of the } \\
\text { Americans' Changing Lives } \\
\text { study }\end{array}$ & $\begin{array}{l}\text { Annual average } \mathrm{PM}_{2.5} \text { concentration } \\
\text { in } 2001 \text { in the area of residence by } \\
\text { linking respondents with EPA air } \\
\text { monitoring data using census tract } \\
\text { identifiers. Exposure to } \\
\text { neighborhood social stressors using } \\
\text { perceptions of disorder and decay } \\
\text { including subjective evaluations of } \\
\text { neighborhood upkeep, presence of } \\
\text { deteriorating/abandoned buildings, } \\
\text { trash, and empty lots. }\end{array}$ & $\begin{array}{c}\text { Error rate on Short Portable } \\
\text { Mental Status Questionnaire } \\
\text { (SPMSQ). }\end{array}$ & $\begin{array}{l}\text { Association between higher rates of } \\
\text { cognitive errors with high } \\
\text { concentrations of } \mathrm{PM}_{2.5} \text { which was } \\
\text { stronger in high stress } \\
\text { neighborhoods indicating towards a } \\
\text { possible role of social stressors and } \\
\text { environmental hazards } \\
\text { No statistically significant gender } \\
\text { based differences found }\end{array}$ \\
\hline 12 & $\begin{array}{c}\text { Alvarez-Pedrerol (2017) } \\
\text { [12] }\end{array}$ & Barcelona, Spain & $\begin{array}{l}1234 \text { children aged } 7-10 \text { years } \\
\text { from } 39 \text { schools who commuted } \\
\text { to school by foot }\end{array}$ & $\begin{array}{l}\text { TRAP exposure (Average } \mathrm{PM}_{2.5} \\
\text { Black Carbon (BC) and } \mathrm{NO}_{2} \\
\text { concentrations) for the shortest } \\
\text { walking route to school }\end{array}$ & $\begin{array}{l}\text { Working Memory (the } \\
\text { three-back numbers test) and } \\
\text { inattentiveness (hit reaction } \\
\text { time standard error of the } \\
\text { Attention Network Test) }\end{array}$ & $\begin{array}{l}\mathrm{PM}_{2.5} \text { and Black Carbon were } \\
\text { associated with a reduction in the } \\
\text { growth of working memory with no } \\
\text { significant association of working } \\
\text { memory with } \mathrm{NO}_{2} \\
\text { Associations of } \mathrm{TRAP} \\
\text { concentrations (BC and } \mathrm{PM}_{2.5} \text { ) and } \\
\text { working memory were stronger for } \\
\text { males than females }\end{array}$ \\
\hline 13 & $\begin{array}{c}\text { Cacciottolo et al. (2017) } \\
\text { [15] }\end{array}$ & USA & $\begin{array}{l}3647 \text { women aged } 65 \text { to } 79 \text { years } \\
\text { from Women's Health Initiative } \\
\text { Memory Study (WHIMS) }\end{array}$ & $\mathrm{PM}_{2.5}$ & $\begin{array}{l}\text { Global cognitive decline and } \\
\text { all-cause dementia } \\
\text { APOE } € 4 / 4 \text { status }\end{array}$ & $\begin{array}{c}\text { Residence in places with high } \mathrm{PM}_{2.5} \\
\text { was associated with an increased } \\
\text { risk for global cognitive decline and } \\
\text { all-cause dementia by } 81 \% \text { and } 92 \% \\
\text { respectively, with risk exacerbated } \\
\text { by APOE } € 4 / 4 \text { allele status }\end{array}$ \\
\hline 14 & Chen et al. (2017) [32] & Ontario, Canada & $\begin{array}{l}\text { All Ontario residents who were } \\
55-85 \text { years old on } 1 \text { April 2001, } \\
\text { Canadian-born, and free of } \\
\text { physician-diagnosed dementia } \\
\text { who were followed up to } 2013\end{array}$ & $\begin{array}{l}\text { Long-term average residential } \\
\text { exposure to Air Pollutants including } \\
\mathrm{PM}_{2.5}, \mathrm{NO}_{\mathrm{s}} \text { and ozone }\end{array}$ & Dementia incidence & $\begin{array}{l}\text { Every interquartile-range increase in } \\
\text { exposure to } \mathrm{M}_{2.5} \text { and } \mathrm{NO}_{2} \text { even at } \\
\text { low levels of air pollution associated } \\
\text { with higher incidence of dementia } \\
\text { No statistically significant gender } \\
\text { based differences }\end{array}$ \\
\hline 15 & $\begin{array}{c}\text { Colicino et al. (2017) } \\
\text { [33] }\end{array}$ & USA & $\begin{array}{l}428 \text { older men in the Veterans } \\
\text { Affairs (VA) Normative Aging } \\
\text { Study }\end{array}$ & Black carbon & $\begin{array}{c}\text { MMSE Score } \\
\text { Telomere length } \\
\text { C Reactive Protein }\end{array}$ & $\begin{array}{c}\text { Black Carbon associated with lower } \\
\text { cognition. Each doubling in BC level } \\
\text { associated with } 1.57 \text { (95\% CI: } 1.20, \\
2.05 \text { ) times higher odds of low } \\
\text { MMSE scores in individuals with } \\
\text { longer blood Telomere length (OR }= \\
3.23 ; 95 \% \text { CI: } 1.37,7.59 ; \\
p=0.04 \text { for BC-by-TL-interaction). }\end{array}$ \\
\hline
\end{tabular}


Table 3. Cont.

S. No. Author (Year)

Study Site
Study Population Exposure Studied

Composite exposure to indoor and

1439 of 2897 children recruited from 39 schools across Barcelona who participated in the BREATHE project 2012/2013 surious TRAPs such as elemental carbon (EC), nitrogen dioxide $\left(\mathrm{NO}_{2}\right), \mathrm{PM}_{2.5}$ and ultrafine particles (UFP) at school

\section{Outcome Variable Studie}

Isophorone exposure using 2002

National Air Toxics Assessment

Sub population of Early Childhood Longitudinal Study, Birth Cohort $(n=4050)$

1469 participants aged 60 to 85 years from Betula project followed up every five years from 1988 to 2010

(2017) [36]

Umeå, Northern

Sweden

USA

[37]

6900 children enrolled in the Early Childhood Longitudinal Study Birth Cohort

$$
\text { levels }
$$

Home learning environment assessed with a modified Home Observation for Measurement of the Environment (HOME) Inventory
Cumulative annual residential mean of $\mathrm{NO}_{\mathrm{x}}$ (marker of long-term exposure to TRAP)
Standardized math assessment scores as a measure of early cognitive skills.

$$
\text { connes }
$$

idential concentrations of 104

Residential concentrations of 104 ambient air toxins (including trichloroethylene, isophorone) from the National Air Toxics Assessment (2002) at age 9 months as per ZIP codes
Episodic memory
Mathematics Tasks score

-

\section{Cognitive Impact \\ Slower development of working memory in children over 3.5 years period associated with higher schools based exposure to air pollution \\ Did not report analysis stratified by} sex

High isophorone levels

$\left(>0.49 \mathrm{ng} / \mathrm{m}^{3}\right)$ and low HOME score were associated low math scale

score.

Decrement in math scale score was more than the additive effect of each exposure especially in male

$$
\text { children. }
$$

No association between long-term exposure to air pollution especially TRAP and episodic memory.

Did not report analysis stratified by sex

High isophorone levels

$\left(>0.49 \mathrm{ng} / \mathrm{m}^{3}\right)$ were associated with low mathematics task scores in urban and highly populated urban areas

Did not report analysis stratified by sex

TRAP was associated with attentional impairment Daily ambient levels of $\mathrm{NO}_{2}$ and Daily ambient levels of $\mathrm{NO}_{2}$ and
$\mathrm{PM}_{2.5}$ contributed to an estimated $\mathrm{PM}_{2.5}$ contributed to an estimated
equivalent to a 1.1 month delay in equivalent to a 1.1 month delay in
age appropriate improvement in response speed as part of natural developmental trajectory. Boys had worse cognitive performance on Hit Reaction Time with incremental increase of both

Elemental Carbon and $\mathrm{NO}_{2}$ 
Table 3. Cont.

$\begin{array}{lllll}\text { S. No. } & \text { Author (Year) } & \text { Study Site } & \text { Study Population } & \text { Exposure Studied }\end{array}$

21 Tallon et al.

(2017) [39]

USA

3377 participants aged 57 to 85 years (from Wave 2, Augus 2010 to May 2011 in National Social Life, Health, and Aging Project (NSHAP) cohort study
Land use regression was used to assess long-term residential concentrations for size-fractioned

PM and nitrogen oxides. Assessment of road traffic noise opulation based cohort study with 4086 participants

( $n=454 ;$ age $\geq 60$ years from th 2001-2002 National Health and Nutrition Examination Survey).

1469 persons aged 60 to 85 years at inclusion in the Betula project and followed up to 22 years, five years apart between 1988 and 2010
474 children from a birth cohor of 719 newborns enrolled in

Porta et al.

Porta et al.

(2016) [43]
Rome, Italy
$2003-2004$ as part of the GASPI
project evaluated at the age of 7 year
$\mathrm{PM}_{2.5}$ exposure (estimated using GIS-based spatio-temporal models) and nitrogen dioxide $\left(\mathrm{NO}_{2}\right)$ exposures (obtained from EPA monitors).
Chicago Cognitive Function Measure (CCFM)
Air pollutants $\left(\mathrm{NO}_{2}, \mathrm{PM}_{\text {coarse, }}\right.$

$\mathrm{PM}_{2.5}, \mathrm{PM}_{2.5}$ absorbance) during

pregnancy and at birth
Maternal smoking
Cognitive assessment using five neuropsychological sub and an additively calculated global cognitive score

\section{Cognitive Impact}

High $\mathrm{PM}_{2.5}$ exposures associated with decrease in Chicago Cognitive Function Measure scores equivalen to aging by 1.6 years for $\mathrm{PM}_{2.5}$ and 1.9 years for $\mathrm{NO}_{2}$ exposure. Cognitive impact of $\mathrm{PM}_{2.5}$ was modified by stroke, anxiety, stress and mediated by

depression.Cognitive impact of $\mathrm{NO}_{2}$ were mediated by stress with effect modification by impaired activities of daily living. Did not report analysis stratified by sex

Association of air pollutants with cognitive dysfunction was amplified by higher noise exposure at high levels of exposure.

Did not report analysis stratified by

Dose-dependent $1 \%$ increase in urinary 1-hydroxypyrene associated with $1.8 \%$ poorer performance on DSST
Exposure to traffic-related air pollution

Dementia incidence
Participants in the group with the highest exposure to TRAP more likely to be diagnosed with dementia. Did not report analysis stratified by sex

Traffic intensity in a $100 \mathrm{~m}$ buffer around home and an incremental $10 \mu \mathrm{g} / \mathrm{m}^{3}$ higher exposure of $\mathrm{NO}_{2}$ $10 \mu \mathrm{g} / \mathrm{m}^{3}$ higher exposure of $\mathrm{NO}_{2}$
exposure in intra-uterine period was associated reduced verbal IQ and verbal comprehension IQ. Other pollutants also showed negative associations with much larger confidence intervals.

Did not report analysis stratified by 
Table 3. Cont.

$\begin{array}{lllll}\text { S. No. } & \text { Author (Year) } & \text { Study Site } & \text { Study Population } & \text { Exposure Studied }\end{array}$

Land use regression was used to
assess long-term residential

26 Tzivian et al. (2016) [44] Bochum, Essen, and Mülhei, Germany opulation based cohort study with 4086 participants aged $50-80$ years old assess long-term residential

$\mathrm{PM}$ and nitrogen oxides. Assessment of road traffic noise
Cognitive assessment using five neuropsychological subtest Cond apsychological subtests global cognitive score (GCS)

(2)

\section{Cognitive Impact \\ Long-term exposures to AP and traffic noise are negatively} correlated with four subtests including memory and executive functions and GCS in dose-dependent relationship independent of noise exposure e.g., an interquartile range rise in $\mathrm{PM}_{25}$ correlated with verbal fluency, labyrinth test, and immediate and

$$
\text { delayed verbal recall. }
$$

Did not report analysis stratified by

Diagnosis of Mild Cognitive Impairment based on five neuropsychological tests (Vide supra) and subjective memory complaint

Positive dose-dependent association between long-term $\mathrm{PM}_{2.5}$ exposure and mild cognitive impairment and mild cognitive inpairment, mainly amnesic subtype (aMCI)
Did not report analysis stratified by sex

1403 community-dwelling older women aged $65-80$ years without enrolled in the Women's Health Initiative Memory Study (WHIMS), 1996-1998

\section{Cumulative $\mathrm{PM}_{2.5}$ exposure in 1999-2006}

Based on given residential histories and air monitoring data

MRI Brain Greater $\mathrm{PM}_{2.5}$ exposures associated with significantly smaller white matter (WM) volumes in frontal and temporal lobes and corpus callosum (equivalent to 1-2 years of brain ageing), but not of gray matter or hippocampus

Children with a residence less than $50 \mathrm{~m}$ away from major highway had lower nonverbal IQ and lower verbal IQ and visual-motor abilities

1109 mother-child pairs in Prenatal and childhood exposure to 29 Harris et al. (2015) [47]
Eastern Massachusetts,

USA
Project Viva, a prospective birth

cohort study in eastern

Massachusetts (USA) and $\mathrm{PM}_{2.5}$ assessed by distance of residence from roadways and traffic density
Verbal and nonverbal intelligence, visual motor abilities, and visual memory assessed at mean age of 8 years
Equivocal findings for

cross-sectional associations with and childhood exposure to traffic density and $\mathrm{PM}_{25}$ thire to traffic and childhood BC exposures Did not report analysis stratified by 
Table 3. Cont.

\begin{tabular}{|c|c|c|c|c|c|c|}
\hline S. No. & Author (Year) & Study Site & Study Population & Exposure Studied & Outcome Variable Studied & Cognitive Impact \\
\hline 30 & $\begin{array}{c}\text { Peterson et al. (2015) } \\
\text { [48] }\end{array}$ & $\begin{array}{l}\text { New York, } \\
\text { USA }\end{array}$ & $\begin{array}{l}40 \text { children aged } 7 \text { to } 9 \text { years } \\
\text { born to any of the } 665 \text { urban } \\
\text { Latina (Dominican) or African } \\
\text { American women women } 18-35 \\
\text { years old who were not cigarette } \\
\text { smokers or users of other } \\
\text { tobacco products or illicit drugs, } \\
\text { with initial prenatal care by the } \\
\text { 20th week of pregnancy, and } \\
\text { who were free of diabetes } \\
\text { mellitus, hypertension, and } \\
\text { known human } \\
\text { immunodeficiency virus } \\
\text { recruited between } 1998 \text { and } \\
2006 \text { through the local prenatal } \\
\text { care clinics who had completed } \\
\text { survey and who had a full range } \\
\text { of prenatal PAH exposure levels; } \\
\text { no or very low prenatal } \\
\text { exposure to environmental } \\
\text { tobacco smoke (classified by } \\
\text { maternal report validated by } \\
\text { cotinine levels of less than } 15 \\
\mu \mathrm{L} / \mathrm{L} \text { in umbilical cord blood) } \\
\text { and low chlorpyrifos exposure } \\
\text { (below } 4.39 \text { pg/g) } \\
20 \text { children were randomly } \\
\text { selected from above the median } \\
\text { PAH level group and } 20 \text { from } \\
\text { below the median PAH level } \\
\text { group }\end{array}$ & $\begin{array}{c}\text { Prenatal airborne PAH exposure by } \\
\text { the sum of } 8 \\
\text { Nonvolatile PAH: } \\
\text { benzo[a]anthracene, } \\
\text { chrysene/iso-chrysene, } \\
\text { benzo[b]fluoranthene, } \\
\text { benzo[k]fluoranthene, } \\
\text { benzo[a]pyrene, } \\
\text { indeno[1,2,3c,d]pyrene, } \\
\text { dibenzo[a,h]anthracene, and } \\
\text { benzo[g,h,i]perylene. measured } \\
\text { with personal air monitoring of the } \\
\text { mothers over a 48-h period in the } \\
\text { third trimester of pregnancy but } \\
\text { assumed to be index exposure for } \\
\text { the entire gestation } \\
\text { Prenatal PAH exposures validated } \\
\text { against concurrent 2-week } \\
\text { monitoring of residential air } \\
\text { samples in the final trimester of } \\
\text { pregnancy } \\
\text { Postnatal PAH exposure by spot } \\
\text { urine sample at age of } 5 \text { years for } 9 \\
\text { metabolites (1-Hydroxynaphthalene, } \\
\text { 2 } \\
\text { Hydroxynaphthalene, } \\
\text { 2-Hydroxyfluorene, } \\
\text { 3-Hydroxyfluorene, } \\
\text { 9-Hydroxyfluorene, } 1 \\
\text { Hydroxyphenanthrene, } \\
\text { 2-Hydroxyphenanthrene, } \\
\text { 3-Hydroxyphenanthrene, and } 4 \\
\text { Hydroxyphenanthren.) }\end{array}$ & $\begin{array}{l}\text { CBCL WISC-IV } \\
\text { MRI Brain }\end{array}$ & $\begin{array}{l}\text { A dose-response inverse } \\
\text { relationship between prenatal PAH } \\
\text { exposure and reductions of the } \\
\text { white matter surface in most of the } \\
\text { frontal, superior temporal, and } \\
\text { parietal lobes, as well as the entire } \\
\text { rostrocaudal extent of the mesial } \\
\text { surface, in the left but not the right } \\
\text { hemisphere of the brain and } \\
\text { reduced white matter in later } \\
\text { childhood associated with slower } \\
\text { information processing speed } \\
\text { during intelligence testing and more } \\
\text { severe externalizing behavioral } \\
\text { problems such as ADHD and } \\
\text { Conduct disorder. } \\
\text { Postnatal PAH exposure correlated } \\
\text { with white matter surface measures } \\
\text { in bilateral dorsal prefrontal cortex } \\
\text { bilaterally independent of prenatal } \\
\text { PAH exposure } \\
\text { Stronger inverse associations of } \\
\text { prenatal PAH exposure with white } \\
\text { matter surface measures in girls as } \\
\text { compared to boys }\end{array}$ \\
\hline 31 & $\begin{array}{l}\text { Schiko-wski et al. } \\
\text { (2015) [49] }\end{array}$ & $\begin{array}{l}\text { Ruhr Area and Borken, } \\
\text { Germany }\end{array}$ & $\begin{array}{l}4874 \text { women from the SALIA } \\
\text { cohort (aged } 55 \text { years at } \\
\text { baseline) enrolled between } 1985 \\
\text { and } 1994 \text { and followed up in } \\
2006(n=2116) \text { and } 2008 \\
(n=834) \text { of which complete } \\
\text { information available }(n=789)\end{array}$ & $\begin{array}{c}\text { Particulate matter }(\mathrm{PM}) \text { size } \\
\text { fractions and nitrogen oxides }\left(\mathrm{NO}_{\mathrm{x}}\right) \\
\text { Traffic load }\end{array}$ & $\begin{array}{l}\text { CERAD-Plus test } \\
\text { Apolipoprotein E (ApoE) alleles }\end{array}$ & $\begin{array}{c}\text { Air pollution was inversely related } \\
\text { to visuospatial abilities on cognitive } \\
\text { assessment with significant adverse } \\
\text { association of traffic load in carriers } \\
\text { of ApoE } € 4 \text { risk alleles. }\end{array}$ \\
\hline
\end{tabular}


Table 3. Cont.

\begin{tabular}{|c|c|c|c|c|c|c|}
\hline S. No. & Author (Year) & Study Site & Study Population & Exposure Studied & Outcome Variable Studied & Cognitive Impact \\
\hline 32 & Sunyer et al. (2015) [50] & Barcelona, Spain & $\begin{array}{l}2715 \text { children aged } 7 \text { to } 10 \text { years } \\
\text { from } 39 \text { schools in Barcelona }\end{array}$ & $\begin{array}{c}\text { Chronic traffic air pollution } \\
\text { [elemental carbon [(EC), nitrogen } \\
\text { dioxide }\left(\mathrm{NO}_{2)} \text {, and ultrafine particle }\right. \\
\text { number (UFP; } 10-700 \mathrm{~nm})] \\
\text { measured twice during 1-wk } \\
\text { campaigns both in the courtyard } \\
\text { (outdoor) and inside the classroom } \\
\text { (indoor) }\end{array}$ & $\begin{array}{l}n \text {-back and the attentional } \\
\text { network tests }\end{array}$ & $\begin{array}{l}\text { Detrimental associations between } \\
\text { Traffic related air pollution and } \\
\text { cognitive performance were } \\
\text { stronger in boys than in girls }\end{array}$ \\
\hline 33 & $\begin{array}{l}\text { Ailshire and Clarke } \\
\text { (2014) }\end{array}$ & $\begin{array}{l}\text { USA } \\
{[51]}\end{array}$ & $\begin{array}{c}\text { Cross sectional data of } 780 \\
\text { non-Hispanic black and white } \\
\text { men and women aged } \\
\geq 55 \text { years from the } 2001 / 2002 \\
\text { Americans' Changing Lives } \\
\text { Study }\end{array}$ & $\begin{array}{l}\mathrm{PM}_{2.5} \text { using PA air monitoring data } \\
\text { linked to respondents using census } \\
\text { tract identifiers. }\end{array}$ & $\begin{array}{c}\text { Tests of working memory and } \\
\text { orientation }\end{array}$ & $\begin{array}{l}\text { Exposure to high } \mathrm{PM}_{2.5} \\
\text { concentrations associated with } \\
1.5 \text { times greater error rate } \\
\text { Male gender was associated with } \\
\text { more cognitive errors }\end{array}$ \\
\hline 34 & $\begin{array}{l}\text { Ailshire and Crimmins } \\
\text { (2014) [52] }\end{array}$ & USA & $\begin{array}{c}13,996 \text { men and women aged } \\
50 \text { years or older from the } 2004 \\
\text { HRS survey }\end{array}$ & $\begin{array}{l}\text { Residence in areas with higher } \\
\mathrm{PM}_{2.5} \text { concentrations }\end{array}$ & Cognitive Function & $\begin{array}{l}\text { Living in areas with higher } \mathrm{PM}_{2.5} \\
\text { concentrations was associated with } \\
\text { worse cognitive function especially } \\
\text { episodic memory } \\
\text { No statistically significant gender } \\
\text { based differences }\end{array}$ \\
\hline 35 & Gatto et al. (2014) [53] & Los Angeles Basin, USA & $\begin{array}{l}1496 \text { individuals (mean age of } \\
60.5 \text { years) }\end{array}$ & $\begin{array}{l}\text { Air pollutants }\left[\mathrm{O}_{3}, \mathrm{PM}_{2.5} \text { and }\right. \\
\left.\text { nitrogen dioxide }\left(\mathrm{NO}_{2}\right)\right]\end{array}$ & $\begin{array}{l}\text { Six domains of cognitive } \\
\text { function and global cognition }\end{array}$ & $\begin{array}{c}\text { Increased exposure to } \mathrm{PM}_{2.5} \\
\text { associated with lower verbal } \\
\text { learning } \\
\text { Exposure to } \mathrm{NO}_{2}>20 \mathrm{ppb} \\
\text { associated with lower logical } \\
\text { memory Exposure to } \mathrm{O}_{3} \text { above } \\
49 \text { ppb associated with lower } \\
\text { executive function } \\
\text { No air pollutant significantly } \\
\text { associated with global cognition. } \\
\text { No statistically significant gender } \\
\text { based differences }\end{array}$ \\
\hline
\end{tabular}


Table 3. Cont.

\begin{tabular}{|c|c|c|c|c|c|c|}
\hline S. No. & Author (Year) & Study Site & Study Population & Exposure Studied & Outcome Variable Studied & Cognitive Impact \\
\hline 36 & Guxens et al. (2014) [54] & $\begin{array}{l}\text { Europe (Netherlands, } \\
\text { Germany, France, Italy, } \\
\text { Greece, Spain) }\end{array}$ & $\begin{array}{c}\text { Mother-, infant pairs recruited } \\
\text { between } 1997 \text { to } 2008 \text { yielding a } \\
\text { total sample of } 9482 \text { children } \\
\text { from } 6 \text { European } \\
\text { population-based birth } \\
\text { cohorts-GENERATION R (The } \\
\text { Netherlands), DUISBURG } \\
\text { (Germany), EDEN (France), } \\
\text { GASPII (Italy), RHEA (Greece), } \\
\text { and INMA (Spain) }\end{array}$ & $\begin{array}{l}\text { Prenatal exposure to air pollutants } \\
\text { such as }\left(\mathrm{NO}_{2}, \mathrm{NO}_{\mathrm{x}}\right) \text { in all regions } \\
\text { and } \mathrm{PM}\left(\mathrm{PM}_{2.5}, \mathrm{PM}_{10} \text { and } \mathrm{PM}_{\text {coarse }}\right) \\
\text { and } \mathrm{PM}_{2.5} \text { absorbance in a subgroup } \\
\text { using land-use regression models } \\
\text { for the period } 2008 \text { to } 2011 \text { and then } \\
\text { modelled for air pollutant profile for } \\
\text { the exact pregnancy periods using } \\
\text { background monitoring sites. }\end{array}$ & $\begin{array}{l}\text { Assessment for cognitive and } \\
\text { psychomotor development at } 1 \\
\text { and } 6 \text { years of age. }\end{array}$ & $\begin{array}{c}\text { Prenatal air pollution exposure } \\
\text { during pregnancy, particularly } \mathrm{NO}_{2} \text {, } \\
\text { was associated with dose-dependent } \\
\text { reduction in psychomotor } \\
\text { development but not cognitive } \\
\text { development. } \\
\text { Did not report analysis stratified by } \\
\text { sex }\end{array}$ \\
\hline 37 & $\begin{array}{l}\text { Tonne et al. } \\
\text { (2014) [55] }\end{array}$ & London, UK & $\begin{array}{l}2867 \text { white men retired from } \\
\text { work (mean age } 66 \text { years) from } \\
\text { Whitehall II cohort }\end{array}$ & $\begin{array}{c}\text { Particulate matter from traffic } \\
\text { exhaust }\end{array}$ & $\begin{array}{l}\text { Alice Heim } 4 \text {-I test, } 20 \text {-word } \\
\text { free-recall test, semantic and } \\
\text { phonemic verbal fluency }\end{array}$ & $\begin{array}{l}\text { Higher } \mathrm{PM}_{2.5} \text { of } 1.1 \mu \mathrm{g} / \mathrm{m}^{3} \text { was } \\
\text { negatively associated with } \\
\text { reasoning and memory but not } \\
\text { verbal fluency and significant } 5 \text {-year } \\
\text { decline in standardized memory } \\
\text { score. }\end{array}$ \\
\hline 38 & Loop et al. (2013) [56] & USA & $\begin{array}{l}20,150 \text { men and women enrolled } \\
\text { in the REasons for Geographic } \\
\text { And Racial Differences1 in } \\
\text { Stroke (REGARDS) cohort }\end{array}$ & $\begin{array}{l}\text { Satellite-derived estimate of } \mathrm{PM}_{2.5} \\
\text { concentration map }\end{array}$ & Cognition & $\begin{array}{c}\text { No consistent increase in odds of } \\
\text { cognitive impairment with every } \\
10 \mu \mathrm{g} / \mathrm{m}^{3} \text { increase in } \mathrm{PM}_{2.5} \\
\text { concentration. } \\
\text { No statistically significant gender } \\
\text { based differences }\end{array}$ \\
\hline 39 & Power et al. (2013) [57] & USA & $\begin{array}{l}628 \text { men (mean age of } 70 \text { years) } \\
\text { from the VA Normative Aging } \\
\text { Study }\end{array}$ & $\begin{array}{l}\text { TRAP exposure on cognitive } \\
\text { function. }\end{array}$ & $\begin{array}{l}\text { HFE C282Y variant } \\
\text { (hemochromatosis gene } \\
\text { polymorphisms) } \\
\text { Cognitive function }\end{array}$ & $\begin{array}{l}\text { Older adults lacking HFE C282Y } \\
\text { variant had greater adverse } \\
\text { cognitive impact of TRAP exposure }\end{array}$ \\
\hline 40 & Weuve et al. (2012) [58] & USA & $\begin{array}{l}19,409 \text { US women aged } 70 \text { to } \\
81 \text { years from Nurses' Health } \\
\text { Study Cognitive Cohort }\end{array}$ & $\begin{array}{l}\text { Long-term exposure to higher levels } \\
\text { of both } \mathrm{PM}_{2.5-10} \text { and } \mathrm{PM}_{2.5}\end{array}$ & Cognition & $\begin{array}{l}\text { Dose-dependent association } \\
\text { between Long-term exposure to } \\
\text { higher levels of both } \mathrm{PM}_{2.5-10} \text { and } \\
\mathrm{PM}_{2.5} \text { and significantly faster } \\
\text { cognitive decline at } 2 \text { years. } \\
\text { Every } 10 \mu \mathrm{g} / \mathrm{m}^{3} \text { increment in } \\
\text { long-term }(2 \text { years }) \text { exposure to } \\
\mathrm{PM}_{2.5-10} \text { and } \mathrm{PM}_{2.5} \text { cognitively } \\
\text { equivalent to aging by } \\
\text { approximately } 2 \text { years. }\end{array}$ \\
\hline 41 & Power et al. (2011) [59] & USA & $\begin{array}{l}680 \text { men (mean } \pm S D \text {, } \\
71 \pm 7 \text { years of age) from the } \\
\text { U.S. Department of Veterans } \\
\text { Affairs Normative Aging Study }\end{array}$ & $\begin{array}{l}\text { Traffic-related air pollution } \\
\text { including Black carbon }(\mathrm{BC}) \\
\text { exposure }\end{array}$ & $\begin{array}{l}\text { Mini Mental Status Examination } \\
\text { (MMSE) }\end{array}$ & $\begin{array}{c}\text { Significant association between } \\
\text { Black carbon (BC) exposure and } \\
\text { lower MMSE score }\end{array}$ \\
\hline
\end{tabular}


Table 3. Cont.

\begin{tabular}{|c|c|c|c|c|c|c|}
\hline S. No. & Author (Year) & Study Site & Study Population & Exposure Studied & Outcome Variable Studied & Cognitive Impact \\
\hline 42 & $\begin{array}{c}\text { Edwards et al. (2010) } \\
\text { [60] }\end{array}$ & Krakow Poland & $\begin{array}{l}214 \text { offspring of a cohort of } \\
\text { pregnant, healthy, nonsmoking } \\
\text { women of Krakow, Poland, } \\
\text { between } 2001 \text { and } 2006\end{array}$ & $\begin{array}{l}\text { Maternal 48-hr personal air } \\
\text { monitoring to estimate foetal } \\
\text { Polyaromatic Hydrocarbon air } \\
\text { pollutant exposure and PAH } \\
\text { estimation from maternal blood } \\
\text { sample and/or a cord blood sample } \\
\text { at the time of delivery }\end{array}$ & $\begin{array}{c}\text { Raven's Coloured Progressive } \\
\text { Matrices (RCPM) at } 5 \text { years of } \\
\text { age }\end{array}$ & $\begin{array}{l}\text { Higher (above the median of } \\
17.96 \mathrm{ng} / \mathrm{m}^{3} \text { ) prenatal exposure to } \\
\text { airborne PAHs associated with } \\
\text { decreased scores on RCPM } \\
\text { corresponding to an estimated } \\
\text { average decrease of 3.8 IQ points. } \\
\text { Did not report gender-based } \\
\text { differences }\end{array}$ \\
\hline 43 & Freire et al. (2010) [61] & Spain & $\begin{array}{l}210 \text { boys from a } \\
\text { population-based birth cohort } \\
\text { from southern Spain }\end{array}$ & $\mathrm{NO}_{2}$ & Cognitive development & $\begin{array}{l}\text { No significant association between } \\
\mathrm{NO}_{2} \text { and cognitive development }\end{array}$ \\
\hline 44 & $\begin{array}{l}\text { Chen and Schwartz } \\
\text { (2009) [62] }\end{array}$ & USA & $\begin{array}{c}1764 \text { adult participants (aged } \\
37.5 \pm 10.9 \text { years) of the Third } \\
\text { National Health and Nutrition } \\
\text { Examination Survey in } \\
1988-1991\end{array}$ & $\begin{array}{l}\text { Geocoded Residential Ambient } \\
\text { annual } \mathrm{PM}_{10} \text { and ozone }\end{array}$ & $\begin{array}{c}\text { Neurobehavioral Evaluation } \\
\text { System-2 (NES2) data } \\
\text { (including a simple reaction } \\
\text { time test [SRTT] measuring } \\
\text { motor response speed to a } \\
\text { visual stimulus; a symbol-digit } \\
\text { substitution test [SDST] for } \\
\text { coding ability; and a serial-digit } \\
\text { learning test [SDLT] for } \\
\text { attention and short-term } \\
\text { memory }\end{array}$ & $\begin{array}{l}\text { Consistent associations between } \\
\text { ozone and not } \mathrm{PM}_{10} \text { and reduced } \\
\text { performance on symbol-digit } \\
\text { substitution test and a serial-digit } \\
\text { learning test but not in simple } \\
\text { reaction time test. } \\
\text { Each 10-ppb increase in annual } \\
\text { ozone was associated with } \\
\text { equivalent to } 3.5 \text { and } 5.3 \text { years of } \\
\text { aging-related decline in cognitive } \\
\text { performance. } \\
\text { Did not report analysis stratified by } \\
\text { sex }\end{array}$ \\
\hline 45 & Perera et al. (2009) [63] & New York, USA & $\begin{array}{l}249 \text { Children born to } \\
\text { nonsmoking black or } \\
\text { Dominican-American women } \\
\text { residing in New York City who } \\
\text { had undergone prenatal } \\
\text { ambient personal PAH } \\
\text { monitoring }\end{array}$ & PAH exposure & $\begin{array}{l}\text { Wechsler Preschool and Primary } \\
\text { Scale of Intelligence-Revised } \\
\text { (WPPSI-R) }\end{array}$ & $\begin{array}{l}\text { High Prenatal Polyaromatic } \\
\text { Hydrocarbons (PAH) levels (above } \\
\text { the median of } 2.26 \mathrm{ng} / \mathrm{m}^{3} \text { ) inversely } \\
\text { associated with full-scale IQ and } \\
\text { verbal IQ with a decrement of } 4.31 \\
\text { to } 4.67 \text { points of IQ at age of } 5 \text { years } \\
\text { Did not report analysis stratified by } \\
\text { sex }\end{array}$ \\
\hline 46 & Ranft et al. (2009) [64] & Germany & 399 women aged $68-79$ years & Traffic-related fine PM & $\begin{array}{l}\text { Mild Cognitive Impairment } \\
\text { (MCI) }\end{array}$ & $\begin{array}{l}\text { Exposure to traffic-related fine PM } \\
\text { consistent and significant risk factor } \\
\text { for MCI }\end{array}$ \\
\hline
\end{tabular}


Table 3. Cont.

\begin{tabular}{|c|c|c|c|c|c|c|}
\hline S. No. & Author (Year) & Study Site & Study Population & Exposure Studied & Outcome Variable Studied & Cognitive Impact \\
\hline 47 & Lee et al. (2007) [65] & USA & $\begin{array}{l}278 \text { children aged } 12-15 \text { years } \\
\text { included in the National Health } \\
\text { and Nutrition Examination } \\
\text { Survey 1999-2000 }\end{array}$ & $\begin{array}{c}\text { POPs such as } \\
\text { 3,3',4,4',5-pentachlorobiphenyl, } \\
\text { 1,2,3,4,6,7,8-heptachlorodibenzo-p- } \\
\text { dioxin (HPCDD), } \\
\text { 1,2,3,4,6,7,8,9-octachlorodibenzo-p- } \\
\text { dioxin (OCDD), } \\
\text { 1,2,3,4,6,7,8- } \\
\text { heptachlorodibenzofuran (HPCDF), } \\
\text { beta-hexachlorocyclohexane, p,p'- } \\
\text { dichlorodiphenyltrichloroethane, } \\
\text { and trans-nonachlor. }\end{array}$ & $\begin{array}{l}\text { Prevalence rates of learning } \\
\text { disability (LD) and attention } \\
\text { deficit hyperactivity disorder } \\
\text { (ADHD), both of which are } \\
\text { characterized by cognitive } \\
\text { impairment }\end{array}$ & $\begin{array}{l}\text { Direct association between POPs } \\
\text { and LD/ADHD. } \\
\text { No statistically significant gender } \\
\text { based differences found }\end{array}$ \\
\hline B & \multicolumn{6}{|c|}{ Stduies from Upper and Middle Income Settings } \\
\hline 1 & $\begin{array}{l}\text { Saenz et al. } \\
\text { (2018) [66] }\end{array}$ & Mexico & $\begin{array}{l}\text { 13,023 Mexican adults over age } \\
50 \text { participating in } 2012 \text { Wave of } \\
\text { the Mexican Health and Aging } \\
\text { Study }\end{array}$ & $\begin{array}{l}\text { Indoor air pollution (Use of wood or } \\
\text { coal as primary cooking fuel) }\end{array}$ & $\begin{array}{l}\text { Verbal learning, verbal recall, } \\
\text { attention, orientation and verbal } \\
\text { fluency }\end{array}$ & $\begin{array}{l}\text { Exposure to indoor air pollution } \\
\text { associated with poorer cognitive } \\
\text { performance } \\
\text { Did not report analysis stratified by } \\
\text { sex }\end{array}$ \\
\hline 2 & Zhang et al. (2018) [67] & China & $\begin{array}{c}25,486 \text { individual respondents } \\
\text { over age } 10 \text { in } 2010 \text { and } 2014, \\
\text { from China Family Panel } \\
\text { Studies (CFPS) }\end{array}$ & $\begin{array}{l}\text { Cumulative and transitory } \\
\text { exposures to air pollution }\end{array}$ & Verbal and Math tests & $\begin{array}{l}\text { Adverse cognitive impact of air } \\
\text { pollution on performance in verbal } \\
\text { and math tests with greater deficits } \\
\text { on verbal tasks as people aged. } \\
\text { Significantly worse verbal tests } \\
\text { performance in males on verbal } \\
\text { tasks with short-term and } \\
\text { cumulative air pollution exposure }\end{array}$ \\
\hline 3 & $\begin{array}{l}\text { Calderón-Garcidueñas } \\
\text { et al. (2012) [68] }\end{array}$ & Mexico & $\begin{array}{l}30 \text { children ( } 20 \text { from Southwest } \\
\text { Mexico City (SWMC) and } 10 \\
\text { from Polotitlan) }\end{array}$ & $\begin{array}{l}\text { High pollution versus low pollution } \\
\text { areas }\end{array}$ & $\begin{array}{l}\text { Frontal tau } \\
\text { hyperphosphorylation with } \\
\text { pre-tangle material } \\
\text { amyloid-beta diffuse plaques }\end{array}$ & $\begin{array}{c}\text { Nearly } 40 \% \text { of highly exposed } \\
\text { children and young adults had } \\
\text { frontal tau hyperphosphorylation } \\
\text { with pre-tangle material and } 51 \% \\
\text { had amyloid-beta diffuse plaques } \\
\text { compared versus } 0 \% \text { of controls } \\
\text { living in low pollution areas. } \\
\text { Did not report analysis stratified by } \\
\text { sex }\end{array}$ \\
\hline
\end{tabular}


Table 3. Cont.

$\begin{array}{lllll}\text { S. No. } & \text { Author (Year) } & \text { Study Site } & \text { Study Population } & \text { Exposure Studied }\end{array}$

20 children from Mexico City (Mean age $=7.1$ years,

- Calderón-Garcidueñas

et al. (2011) [69]

Mexico

Polotitlán (Mean age $=6.8$ years, $\mathrm{SD}=0.66)$
$\mathrm{SD}=0.69)$ and 10 children from
High pollution Areas versus Low

pollution areas
MRI Brain

Wechsler Intelligence Scale for Children-Revised (WISC-R)

Inflammatory markers

interleukin 12 , cytokines and

chemokines

\section{Cognitive Impact}

Complex modulation of cytokines and chemokines influences

children's central nervous system structural and volumetric response and cognitive correlates resulting from environmental pollution exposures

Did not report analysis stratified by

exposure high pollution associated with low white matter volumes with low white especially in the right parietal and of white mattal areas irrespective of white matter abnormalities as well as progressive deficits on WISC-R Vocabulary and Digit Span subtests

\section{White matter hyperintensities} associated with evidence of inflammation, immunoregulation, and tissue remodeling on MRI.

Children without white matter

hyperintensities had raised levels of interleukin 12, pro-inflammatory

cytokines, and low levels of neuroprotective cytokines and chemokines.

(Continued)

Did not report analysis stratified by

Residence in high air pollution area

associated with deficits in a
55 Children (mean age:

9.2 years) from Mexico City

children (mean age: 10.5 years)

from Polotitlán with with high air pollution and 18
Air Quality

Psychometric testing MRI Brain et al. (2008) [13]
[13
Mexico crystallized cognition tasks, high

rates of prefrontal white matter hyperintense lesions

Did not report analysis stratified by 


\subsection{Research from $\mathrm{LMICS} / \mathrm{LICS}$}

Among the studies, 89\% were conducted in HICs, while only $11 \%$ of studies were conducted in UMICs. There was no original research from either LMICs or LICs as per World Bank income levels, despite high levels of air pollution (Appendix B).

\subsection{Gender-Based Analysis}

A review of 53 original studies revealed that most studies did not report gender-based findings $(n=28)$, and an equal number $(n=7)$ reported significant gender differences and no gender differences. Six studies were conducted on female participants, while five studies researched only male participants. (Figure 3).
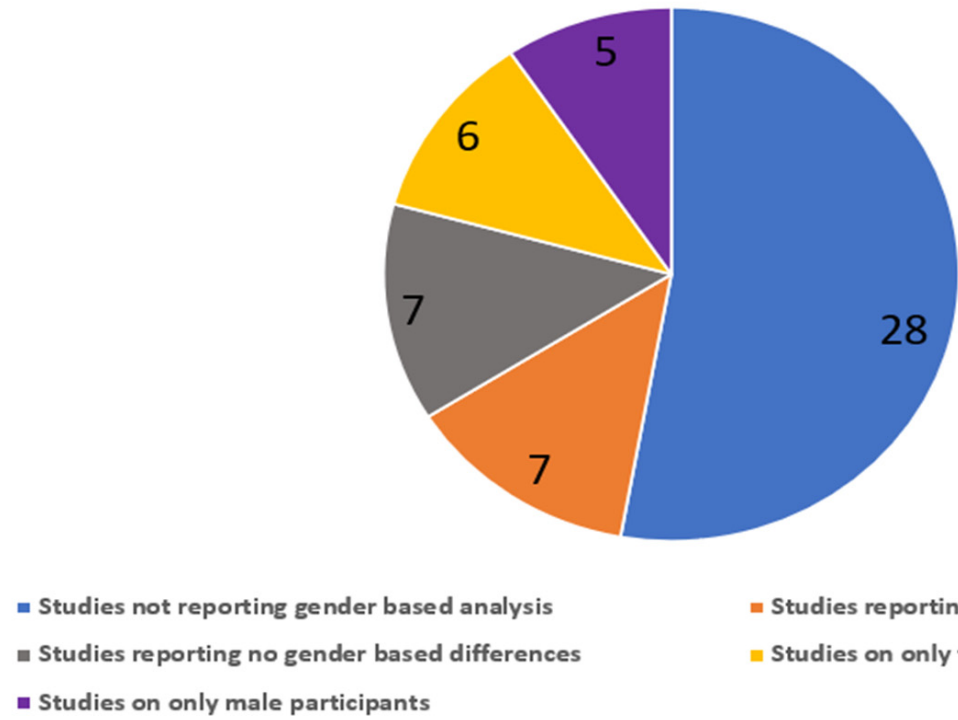

Figure 3. Gender-based reporting in original studies on air-pollution-associated cognitive impairment.

\subsection{Analysis Based on Life Course and Income Level of Study Areas}

The results of the studies were analyzed based on the life-course stage (children and adolescents prenatal and postnatal exposures, adults and older adults) and on the income level of the study areas are presented below.

3.5.1. Studies Related to Air Pollution and Cognitive Impairment in Children and Adolescents

Prenatal Exposure Studies

Prenatal exposure to different air pollutants has been analyzed for cognitive and other developmental indicators from infancy through adolescence using birth cohorts.

\section{Multiple Air Pollutants}

Two European studies found that exposure to multiple air pollutants in the prenatal period and infancy (until 1 year of age) had an adverse impact on psychomotor development and cognitive performance, adaptive functioning, and behavioral indices.

Guxens et al. analyzed data from 9482 children from mother-infant pairs recruited between 1997 to 2008 in 6 European population-based birth cohorts, namely GENERATION R (Netherlands), DUISBURG (Germany), EDEN (France), GASPII (Italy), RHEA (Greece), and INMA (Spain) [54]. Prenatal exposures to $\mathrm{NO}_{2}$ and nitrogen oxides $\left(\mathrm{NO}_{\mathrm{x}}\right)$ for the exact pregnancy periods in all regions and $\mathrm{PM}\left(\mathrm{PM}_{2.5}, \mathrm{PM}_{10}, \mathrm{PM}_{2.5-10}, \mathrm{PM}_{2.5}\right.$ absorbance $)$ in some regions were derived from background monitoring sites as well as land-use regression models for the period 2008 to 2011. Children were later assessed by a physician between 1 and 6 years of age. Prenatal air pollution exposure was associated with dose-dependent reduction in psychomotor development, where results of the different tests on average 
declined 0.68 points, with a $95 \%$ confidence interval (CI) of -1.25 to -0.11 per $10 \mu \mathrm{g} / \mathrm{m}^{3}$ increase in $\mathrm{NO}_{2}$. No such associations were seen for cognitive impairment.

In another study from California, U.S., prenatal air pollutant exposure and first year of life exposure to $\mathrm{NO}_{2}, \mathrm{PM}_{2.5}, \mathrm{PM}_{10}$, ozone $\left(\mathrm{O}_{3}\right)$, and near-roadway air pollution was associated with impaired cognitive performance, adaptive functioning, and behavioral indices among children with Autism Spectrum Disorder (ASD) $(n=327)$, but not severity of ASD [29]. However, third trimester $\mathrm{PM}_{10}$ exposure was paradoxically associated with improved behavioral performance in this study.

A Mexican study also reported diffuse neuroinflammation, damage to the neurovascular unit and production of autoantibodies to neural and tight-junction proteins among children chronically exposed to higher concentrations of ozone and $\mathrm{PM}_{2.5}$ in Mexico. Such physiological responses enhance the risk of developing Alzheimer's disease later in life [68].

\section{Traffic-Related Air Pollution (TRAP)}

Similarly, prenatal exposure to TRAP was found to have an adverse impact on intelligence quotient (IQ) in two separate birth cohort studies in the U.S. and Italy.

Project Viva, a cohort of 1109 mother-child pairs in eastern Massachusetts, U.S.A, investigated the impact of prenatal and childhood exposure to TRAP, including black carbon (BC) and $\mathrm{PM}_{2.5}$ based on proximity to roadways and traffic density, on childhood cognition [47]. At a mean age of 8 years, children with a residence located less than $50 \mathrm{~m}$ away from a major highway had lower nonverbal IQ ( -7.5 points; $95 \%$ CI: $-13.1,-1.9)$, verbal IQ ( -3.8 points; $95 \%$ CI: $-8.2,0.6)$ and visual-motor abilities $(-5.3$ points; $95 \%$ CI: $-11.0,0.4)$. Findings for cross-sectional associations between major roadway proximity and (1) prenatal and childhood exposure to traffic density, (2) prenatal and childhood exposure to $\mathrm{PM}_{2.5}$, and (3) third trimester and childhood exposure to $\mathrm{BC}$ were equivocal. In a study in Rome, Italy, the cognition of children aged 7 years $(n=474)$ who belonged to a birth cohort of 719 newborns was investigated [43]. The authors found that both traffic intensity within a $100 \mathrm{~m}$ buffer around the home and incremental increases (per $10 \mu \mathrm{g} / \mathrm{m}^{3}$ ) of intrauterine $\mathrm{NO}_{2}$ exposure were associated with reduced verbal IQ and verbal comprehension IQ (on Wechsler Intelligence Scale for Children-III). Other pollutants also showed negative associations but with much wider confidence intervals.

\section{Particulate Matter (PM)}

Prenatal PM exposure was found to have a deleterious impact on brain volumes in a neuroimaging study, demonstrating the neurological basis of impaired cognition in children exposed prenatally to air pollutants in previous studies.

A dose-dependent thinning of cerebral cortex per $5 \mu \mathrm{g} / \mathrm{m}^{3}$ increase in prenatal PM exposure in bilateral cerebral hemispheres was demonstrated in children living in Rotterdam, the Netherlands [14]. Reduced cerebral cortex in the precuneus and rostral middle frontal regions partially mediated the association between PM exposure and impaired inhibitory control. However, global brain volumes were not impacted.

\section{Isophorone}

Another cost-effective technique to assess exposure to multiple air pollutants is to study one indicator air pollutant, such as Isophorone (which is a common marker of industrial pollution), and its association with cognitive performance. Isophorone was investigated in a study on residential concentrations of 104 ambient air toxins from the National Air Toxics Assessment (2002). Machine learning algorithms were applied to the cognitive data of 6900 children from the Early Childhood Longitudinal Study Birth Cohort in the U.S.A. Here, a high Isophorone level $\left(>0.49 \mathrm{ng} / \mathrm{m}^{3}\right)$ was associated with low performance on mathematics tasks among children from urban and highly populated urban areas, with their scores being reduced by 1.19 points ( $95 \%$ CI: $-1.94,-0.44$ ) [37].

5. Persistent Organic Pollutants (POPs)

Another set of toxic air pollutants are POPs. Prenatal exposure to POPs such as polychlorinated biphenyls (PCBs), was investigated in adolescents (13-15 years) from 2 
Dutch birth cohorts in the Development at Adolescence and Chemical Exposure (DACE) study [26].

Maternal serum levels of PCBs including 3 hydroxylated variants were measured during pregnancy [26]. There was a significant association between the compound PCB-183 and lower total intelligence, hexabromocyclododecane (HBCDD) and lower performance intelligence, and polybrominated diphenyl ethers (PBDEs) with lower verbal memory. Several hydroxy PCBs (OH-PCBs) were associated with more optimal sustained attention and balance.

Among boys, poorer outcomes on fine motor skills and better outcomes on motor performance were reported, and prenatal DDE levels were associated with suboptimal motor performance, while a positive trend was seen between 4-OH-PCB-107 and fine motor skills. In girls, positive trends between $\mathrm{OH}-\mathrm{PCB}$ and verbal intelligence, and a negative trend between the compound BDE-153 and fine motor skills was observed. The associations persisted even after controlling for confounders such as maternal smoking, alcohol use, and education.

\section{Polyaromatic Hydrocarbons (PAH)}

Prenatal exposure to PAH is another set of pollutants implicated in lower IQ, neuroimaging markers, impaired cognition in children and behavioral conditions such as Attention Deficit Hyperactivity Disorder (ADHD) and Conduct Disorder in separate birth cohort studies and different ethnic populations.

A cohort involving prenatal personal ambient PAH monitoring was created with 665 urban Latina (Dominican) and African-American women, aged 18-35 years, residing in New York city [63]. The following inclusion criteria were applied: non-diabetic, non-hypertensive, not users of tobacco or illicit drugs, initial prenatal care by the 20th week of pregnancy, no known human immunodeficiency virus, low prenatal exposure to environmental tobacco smoke (cotinine levels $<15 \mu \mathrm{g} / \mathrm{L}$ in umbilical cord blood), and low exposure to pesticides (chlorpyrifos levels $<4.39 \mathrm{pg} / \mathrm{g}$ in umbilical cord blood). Results indicate that high prenatal PAH levels $\left(>2.26 \mathrm{ng} / \mathrm{m}^{3}\right)$ were associated with lower IQ $(p=0.007)$ and verbal IQ $(p=0.003)$, with offspring experiencing a decrement of $4.31-4.67$ IQ points at 5 years of age. Neuroimaging of 40 randomly selected children in high and low prenatal PAH exposure groups demonstrated an inverse dose-response relationship with reduction of the white matter surface in the left hemisphere of the brain in later childhood (7-9 years), which is associated with slower information processing speed during intelligence testing and more severe externalizing behavioral conditions such as ADHD and Conduct Disorder [48].

Similarly, a study in Krakow, Poland, monitored healthy, nonsmoking pregnant women's personal prenatal PAH levels $(48 \mathrm{~h})$ and examined blood samples and/or a cord blood samples at the time of delivery. After follow-up of the offspring $(n=214)$, the findings showed that high prenatal PAH exposure $\left(>17.96 \mathrm{ng} / \mathrm{m}^{3}\right)$ was associated with reduced nonverbal reasoning ability on Raven's Coloured Progressive Matrices at 5 years of age, which corresponds to an average IQ decrease of 3.8 points [60].

Postnatal Exposure Studies

Most children continue to be exposed to air pollutants in postnatal periods as well. Several investigators have also explored the impact of postnatal exposure of the air pollutants known to have an adverse cognitive impact on prenatal exposure.

\section{Multiple Air Pollutants}

There has been original research on neuroimaging, neuropathological, and inflammatory markers as biomarkers of impaired cognition associated with postnatal exposure to multiple air pollutants.

Neuroimaging studies have also demonstrated the impact of high air-pollution exposure during the postnatal period on cognition. For instance, an MRI brain study found significant differences in white-matter volumes, especially in the right parietal and bilateral 
temporal areas, of children exposed to high levels of air pollution in Mexico City [69]. These same children had progressive deficits on the "Vocabulary" and "Digit Span" subtests of the Wechsler Intelligence Scale for Children-Revised (WISC-R).

Additionally, children with white-matter hyperintensities showed inflammatory markers, including evidence of inflammation resolution, immunoregulation, and tissue remodeling, while children without white-matter hyperintensities had raised levels of interleukin 12, pro-inflammatory cytokines, and low levels of neuroprotective cytokines and chemokines. The authors postulated that the air-pollution-induced neuroinflammation, characterized by complex modulation of cytokines and chemokines, causes structural and volumetric changes in the central nervous system (CNS) and, thereby, affects cognitive function.

Another study on urban children supports air-pollution-associated neuroinflammation and neuropathology, as nearly $40 \%$ of highly exposed children and young adults had frontal tau hyperphosphorylation with pre-tangle material, and 51\% had amyloid-beta diffuse plaques [68]. Conversely, $0 \%$ of the samples/scans from similar controls living in lowpollution areas showed such effects.

\section{Traffic-Related Air Pollution (TRAP)}

Postnatal TRAP was found to be associated with impaired cognitive performance in four studies, though there is a contradictory study. All studies were from Spain.

Exposure to nitrogen dioxide $\left(\mathrm{NO}_{2}\right), \mathrm{PM}_{2.5}$, and elemental carbon (EC) derived from traffic over 1 year was studied in relation to the attention-related cognitive domain among 2687 primary school children from 39 schools across Barcelona, Spain [38,50]. Results demonstrated that children's attention processes, assessed via a computerized, childfriendly Attention Network Test, were inversely associated with TRAP. Daily ambient levels of $\mathrm{NO}_{2}$ and $\mathrm{PM}_{2.5}$ contributed to an estimated equivalent of a 1.1-month (95\% CI: $0.84,1.37)$ delay in response speed according to the age-appropriate, natural developmental trajectory. Furthermore, boys demonstrated significantly worse cognitive performance on Hit Reaction Time following incremental increases of both $\mathrm{EC}$ and $\mathrm{NO}_{2}$.

Similarly, a study in Catalonia, Spain, explored the cognitive impact of TRAP exposure during the walking commute to school among children aged $7-10$ years old $(n=1234)$ [12]. The authors found that exposure to $\mathrm{PM}_{2.5}$ and $\mathrm{BC}$ was associated with a reduction in the developmental growth of working memory; however, no significant association was seen for NO.

A study conducted in Barcelona, Catalonia, Spain, also found an adverse impact of composite exposure to indoor and outdoor levels of TRAP at school, including $\mathrm{EC}, \mathrm{NO}_{2}$, $\mathrm{PM}_{2.5}$ and ultrafine particles (UFP), on the development of working memory in children over 3.5 years of age $(n=2897)$ [34].

Conversely, Freire et al. found no significant association between $\mathrm{NO}_{2}$ and cognitive development in a population-based birth cohort of 210 children in Spain [61].

3. Persistent Organic Pollutants (POPs)

Similar to prenatal exposure, postnatal exposure to different POPs has been found to have an adverse cognitive impact.

Lee et al. found a direct association between serum concentrations of POPs and the development of a learning disability (LD) and ADHD, both of which are characterized by cognitive impairment [65]. Children between the ages of 12 and 15 ( $n=278)$ were recruited from the National Health and Nutrition Examination Survey in the U.S. (1999-2000). The most commonly detected POPs were 3,3',4,4',5-pentachlorobiphenyl, 1,2,3,4,6,7,8-heptachlorodibenzo-p-dioxin (HPCDD), 1,2,3,4,6,7,8,9-octachlorodibenzo-pdioxin (OCDD), 1,2,3,4,6,7,8-heptachlorodibenzofuran (HPCDF), beta-hexachlorocyclohexane, $\mathrm{p}, \mathrm{p}^{\prime}$-dichlorodiphenyltrichloroethane, and trans-nonachlor.

\section{Isophorone}

Like prenatal exposure, postnatal Isophorone has also been found to be associated with lower performance on mathematical tasks in children. 
Ambient Isophorone exposure was found to be associated with low math scores $(-1.48$; $95 \%$ CI: $-2.79,-0.18)$, independent of the influence of the home-learning environment, on analyzing the 2002 U.S. National Air Toxics Assessment data. Despite no interaction effect, children with both high Isophorone exposure and a low score on Home Observation for Measurement of the Environment Inventory had a decrement in math-scale score beyond the additive effect of individual exposures, especially in males [35].

\subsubsection{Studies Related to Air Pollution and Cognitive Impairment in Adults}

Two studies from the U.S. and China reported impaired cognitive performance associated with exposure to air pollutants on cognitive performance in adults, which was contradicted by another study from the U.S.

Chen and Schwartz found consistent associations in their study of 1764 adults in the United States aged 37.5 ( \pm 10.9 years) using the Third National Health and Nutrition Examination Survey (1988-1991) [62]. The findings demonstrated that long-term exposure to ambient ozone reduced performance on both the symbol-digit substitution test and a serial-digit learning test, but not in simple reaction-time tests. Each 10 parts per billion $(\mathrm{ppb})$ increase in annual ozone was associated with the equivalent of 3.5 and 5.3 years of aging-related decline in cognitive performance (depending on the outcome measure used). Similar associations were not seen for $\mathrm{PM}_{10}$. Another study, in China, on the effects of cumulative and transitory exposure to air pollution on cognitive performance reported an adverse cognitive impact in verbal and math tests with greater deficits on verbal tasks as people aged [67].

However, results from the Reasons for Geographic and Racial Differences in Stroke (REGARDS) cohort found no consistent increase in the odds of cognitive impairment with every $10 \mu \mathrm{g} / \mathrm{m}^{3}$ increase in $\mathrm{PM}_{2.5}$ concentration (55). This was a geographically diverse, biracial U.S. cohort of both sexes $(n=20,150)$ aged $\geq 45$ years with satellite-derived estimates of residential $\mathrm{PM}_{2.5}$ concentrations.

Further studies are required to clarify these contradictory findings, given that cognitive reserve in adults can mask minimal cognitive impairments.

\subsubsection{Studies Related to Air Pollution and Cognitive Dysfunction in the Older Adults}

Like childhood studies, there is extensive literature on the impact of air pollutants on cognition in the elderly.

\section{Air and Noise Pollution}

Several research studies have focussed on combined exposure of air and noise pollution, both of which are potentially deletrious for cognition in the elderly.

A positive exposure-response relationship between dementia and $\mathrm{PM}_{2.5}, \mathrm{NO}_{2}$, but not ozone, was found in a cohort study in England ( $n=30,978$ aged 50-79 years) independent of noise levels [27]. Similarly, in the Betula project, a longitudinal study on health and ageing in Umeå, Sweden, the risk for incident dementia over a 22-year period between 1988 to 2010 was associated with higher residential exposure to $\mathrm{NO}_{\mathrm{x}}(n=1469$ persons aged 60 to 85 years at inclusion) [42]. The authors reported a hazard ratio (HR) of 1.43 (95\% CI: $0.998,2.05)$ for the highest exposure quartile compared to the lowest [42]. The risk for dementia was independent of noise exposure, even in a relatively low-exposure area ( $n=1721$ persons aged $55-85$ years) [25].

However, an additional study investigating associations within the entire Betula dataset ( $n=1469$ aged $60-85)$ showed no association between $\mathrm{NO}_{\mathrm{x}}$ and episodic memory [36].

Research on a Heinz Nixdorf Recall population-based cohort ( $n=4086$ participants, aged 50-80 years from Bochum, Essen, and Mülheim in Germany) revealed that long-term residential exposure to size-fractioned $\mathrm{PM}, \mathrm{NO}_{\mathrm{x}}$, and traffic noise was negatively correlated with four neuropsychological subtests (verbal fluency, a labyrinth test, immediate verbal 
recall, and delayed verbal recall) as well as with global cognitive score (GCS) [44]. Here, the cognitive effects of dose-dependent increases in $\mathrm{PM}_{2.5}$ were independent of noise exposure.

Tzivian et al., furthermore, found a positive dose-dependent association between longterm air pollution exposure and mild cognitive impairment (MCI), mainly amnestic subtype: odds ratio (OR) per interquartile range increase in $\mathrm{PM}_{2.5}$ of 1.16 (95\% CI: 1.05, 1.27) [44]. In a subsequent study, this was found to be amplified by noise exposure, supporting the synergistic negative effect of air pollution and road traffic noise [40]. Similarly, exposure to traffic-related fine PM was also determined to be a consistent and significant risk factor for $\mathrm{MCI}$ in another German study [64].

\section{Multiple Air Pollutants and TRAP}

Similar to other age groups, multiple air-pollutant exposure has been determined to have an adverse impact on cognitive impairment and its concomitants in the elderly.

Only one study has investigated the role of TRAP exposure in impairment of specific cognitive domains using a cohort-based approach. This study on older adults residing in Los Angeles reported an association between $\mathrm{PM}_{2.5}$ exposure and lower verbal learning ( $\beta=-0.32$ per $\left.10 \mu \mathrm{g} / \mathrm{m}^{3} ; 95 \% \mathrm{CI}:-0.63,0.00 ; p=0.05\right)$. Moreover, $\mathrm{NO}_{2}$ exposure over $20 \mathrm{ppb}$ was associated with lower logical memory, and ozone exposure above $49 \mathrm{ppb}$ was associated with lower executive function [53]. Still, none of these pollutants were significantly associated with global cognition.

Similarly, a study on the association between TRAP and cognitive function in 680 elderly participants (aged $71 \pm 7$ years) in the U.S. Department of Veterans Affairs (VA) Normative Aging Study demonstrated a significant relationship between BC exposure and cognitive impairment, assessed using the Mini Mental Status Examination (MMSE) scores. The multivariable-adjusted OR was 1.3 for a doubling in BC concentration (95\% CI: 1.1, 1.6) [59]. TRAP exposure was found to adversely impact reasoning and memory, but not verbal fluency, in a study on 2867 individuals (mean age: 66 years) from the Whitehall II cohort in the United Kingdom. Higher $\mathrm{PM}_{2.5}$ of $1.1 \mu \mathrm{g} / \mathrm{m}^{3}$ (lag 4) was associated with a $0.03(95 \% \mathrm{CI}:-0.06,0.002) 5$-year decline in standardized memory score [55]. In addition, in a study of 3377 elderly participants from the National Social Life, Health, and Aging Project (NSHAP) in the U.S., air pollutant exposure was estimated using GIS-based spatio-temporal models for $\mathrm{PM}_{2.5}$ and Environmental Protection Agency (EPA) monitors for $\mathrm{NO}_{2}$. Here, high $\mathrm{PM}_{2.5}$ exposure was associated with a 0.22 (95\% CI: $\left.-0.44,-0.01\right)$ and high $\mathrm{NO}_{2}$ exposure with a $0.25(95 \% \mathrm{CI}:-0.43,-0.06)$ point decrease in Chicago Cognitive Function Measure test scores; these reductions are equivalent to aging 1.6 years and 1.9 years, respectively. The cognitive impact of $\mathrm{PM}_{2.5}$ was found to be mediated by depression and modified by stroke, anxiety, and stress. On the other hand, the cognitive impact of $\mathrm{NO}_{2}$ was mediated by stress, with impaired activities of daily living causing effect modification [39].

Another study by Molina-Sotomeyer et al. on 181 older women in Chile took into account the confounding effect of cardiorespiratory aerobic exercise for the impact of multiple air pollutants such as $\mathrm{PM}_{10}, \mathrm{PM}_{2.5}, \mathrm{NO}_{2}, \mathrm{SO}_{2}$ and Ozone concentrations on cognition and cardiovascular markers. The authors used maximum oxygen uptake $\left(\mathrm{VO}_{2 \max }\right)$, estimated by the Six-Minute Walk Test (6mWT), heart rate (HR), and oxygen saturation $\left(\mathrm{SpO}_{2}\right)$ as indicators of cardiorespiratory aerobic exercise. They marked significantly lower cognition performance amongst women residing in highly polluted areas as compared to those living in less-polluted areas. However, aerobic exercise was found to be a protective factor against adverse cognitive impact of air pollution, probably due to improvement in the mechanisms of oxygen transport [24].

Additionally, a large study on air pollution exposure and dementia incidence included all Canadian-born Ontario residents aged 55-85 years old and followed them from 2001 to 2013. The findings demonstrated that long-term mean residential exposure to air pollutants, including $\mathrm{PM}_{2.5}, \mathrm{NO}_{2}$ and ozone, was associated with higher dementia incidence, even at the relatively low exposure levels throughout this study setting. The HR was 1.04 (95\% CI: 
$1.03,1.05)$ for every interquartile-range increase in $\mathrm{PM}_{2.5}$ and 1.10 (95\% CI: 1.08, 1.12) for every interquartile increase in $\mathrm{NO}_{2}$ [32]. Lo et al. also reported a significant association between long-term exposure to $\mathrm{PM}_{10}$ and $\mathrm{O}_{3}$ and cognitive impairment in older adults, with ORs of 1.094 (95\% CI: 1.020, 1.174) and 1.878 (95\% CI: 1.363, 2.560), respectively [23]. A greater effect was seen for the combined exposure to $\mathrm{PM}_{10}$ and $\mathrm{O}_{3}(p<0.001)$.

Further, research was conducted on the cross-sectional and cumulative (over 2.8 years) impact of outdoor air pollution exposure (PM and $\mathrm{NO}_{\mathrm{x}}$ ) on cognitive functions of 86,759 middle- to older-aged adults (mean age $56.86 \pm 8.12$ years) from the U.K. Biobank general population cohort. While there was weak association between air pollution exposure and cognitive performance (dose-dependent slower reaction time, higher error rate on a visuospatial memory test, and lower numeric memory scores) at baseline (after adjusting for confounders), no such associations were found at follow-up. The authors did not report analyses stratified by sex [28].

\section{Particulate Matter (PM)}

PM has also been extensively investigated for a dose-response relationship with cognitive impairment in the elderly in several research projects in several high-income settings.

Oudin et al. used a dataset of 1806 participants from the Betula project in Sweden (enrolled between 1993 and 1995 and followed until 2010) to assess the impact of exposures of ambient $\mathrm{PM}_{2.5}$ from residential wood burning and vehicle exhaust. Their results indicated a dose-dependent increased risk of incident dementia (Vascular Dementia and Alzheimer's Disease) per $1 \mu \mathrm{g} / \mathrm{m}^{3}$ increase in $\mathrm{PM}_{2.5}$; reported HRs were 1.55 (95\% CI: $\left.1.00,2.41 ; p=0.05\right)$ for local wood burning and 1.66 (95\% CI: 1.16, 2.39; $p=0.006)$ for traffic exhaust [30].

Similarly, $\mathrm{PM}_{2.5}$ exposure was associated with a 1.5 times greater cognitive error rate in a study on non-Hispanic, older White and Black U.S. adults ( $n=780$; age $\geq 55$ years) from the 2001/2002 Americans' Changing Lives Study. The adverse cognitive impact of $\mathrm{PM}_{2.5}$, was found to be similar among men and women, and possibly mediated by neighborhood social stressors and environmental hazards [31].

A neuroimaging study examining the association between $\mathrm{PM}_{2.5}$ and brain volumes in 1403 community-dwelling older women without dementia from the Women's Health Initiative Memory Study (1996-1998) in Germany found that older women with greater $\mathrm{PM}_{2.5}$ exposure had significantly smaller white matter (WM) volumes in the frontal and temporal lobes and corpus callosum, which is equivalent to 1-2 years of brain ageing [45]. Similar associations were not seen for gray matter (GM) volumes or hippocampal volumes.

Similarly, the 2004 Health and Retirement Study ( $n=13,996$; age $\geq 50$ years $)$ in U.S.A. also implicated high residential exposure to $\mathrm{PM}_{2.5}$ with worse cognitive function: $\beta=-0.26$ (95\% CI: $-0.47,-0.05)$ and strongest negative association for episodic memory [51].

Long-term exposure to high levels of $\mathrm{PM}_{2.5-10}$ and $\mathrm{PM}_{2.5}$ has been associated with faster dose-dependent cognitive decline in older women (aged 70 to 81 years) for every $10 \mu \mathrm{g} / \mathrm{m}^{3}$ increment in long-term (2 years) exposure in the U.S. Nurses' Health Study Cognitive Cohort $(n=19409)$. The corresponding decrements on a global cognitive score following these $\mathrm{PM}_{2.5-10}$ and $\mathrm{PM}_{2.5}$ exposures were 0.020 (95\% CI: $\left.-0.032,-0.008\right)$ and -0.018 (95\% CI: $-0.035,-0.002)$, respectively. The effect of $10 \mu \mathrm{g} / \mathrm{m}^{3}$ higher PM exposure was cognitively equivalent to aging by approximately 2 years [58].

Similarly, Saenz et al. also found that exposure to indoor air pollution, due to the household's primary cooking fuel being wood or coal, was associated with poorer cognitive performance in older adults (over age 50) in Mexico [66].

Lee et al. reported that long-term exposure to a higher concentration of $\mathrm{PM}_{2.5}$ was associated with increased hospitalizations for dementia, with an adjusted HR of 1.049 (95\% CI: $1.048,1.051)$ per $1 \mu \mathrm{g} / \mathrm{m}^{3}$ increase in annual $\mathrm{PM}_{2.5}$. The hazard ratio for vascular dementia was somewhat higher at 1.086 (95\% CI: 1.082, 1.090) [22]. Additionally, hospitalizations for dementia increased slightly as the level of urbanization increased: the HR for rural areas was 1.036 (95\% CI: 1.031, 1.041) vis a vis 1.052 (95\% CI: $1.050,1.054)$ for the metropolitan areas. 
The available literature strongly suggests that air pollution, especially PM, is associated with cognitive disorders in the elderly [70].

Polyaromatic Hydrocarbons (PAH)

There is only one study investigating the dose-dependent relationship between PAH and decline in cognitive performance. This study used the 2001-2002 National Health and Nutrition Examination Survey in the U.S. $(n=454)$ to demonstrate a dose-dependent association between PAH exposure per 1\% increase (assessed by urinary 1-hydroxypyrene) and a decline in performance on digit symbol substitution tests by $1.8 \%$ among those aged $\geq 60$ years [41].

\section{Contribution of Genetic Factors}

Cognitive impairment in the elderly may be associated with genetic factors such as polymorphisms in apolipoprotein E allele (ApoE4 variants) and hemochromatosis gene (HFE C282Y variant). Therefore, it is important that the confounding impact of such genetic factors are investigated to delineate the differential impact of air pollution and genetic loading, which has been investigated in some American and German studies.

Traffic load was a significant factor for cognitive performance among carriers of ApoE $€ 4$ risk alleles. Additionally, research using a cohort from the Women's Health Initiative Memory Study (WHIMS) in the U.S. demonstrated that adverse cognitive effects of living in areas with high $\mathrm{PM}_{2.5}$ concentrations, including an $81 \% \mathrm{HR}$ increase for global cognitive decline and a 92\% HR increase for all-cause dementia, were exacerbated among ApoE $€ 4 / 4$ carriers [15]. Over a follow-up period of 22 years, Schikowski et al. examined the association between neurocognitive functions (assessed using CERAD-Plus) and air-pollution exposure as well as its modification by ApoE alleles among 789 women from the SALIA cohort in Germany [49]. Air pollution was inversely related to visuospatial abilities on figure copying tasks for every interquartile range increase of $\mathrm{NO}_{2}(\beta=-0.28(95 \% \mathrm{CI}:-0.44,-0.12)), \mathrm{NO}_{\mathrm{x}}$ $(\beta=-0.25$ (95\% CI: $-0.40,-0.09)), \mathrm{PM}_{10}(\beta=-0.14(95 \% \mathrm{CI}:-0.26,-0.02))$ and $\mathrm{PM}_{2.5}$ $(\beta=-0.19$ (95\% CI: $-0.36,-0.02))$.

In the Veterans Affairs Normative Aging Study from the U.S., Black Carbon (BC) was reported to be associated with lower cognition ( $n=428$ older men). Each doubling in BC levels was associated with 1.57 (95\% CI: 1.20, 2.05) times higher odds of low MMSE scores in individuals with longer blood telomere length $(\mathrm{OR}=3.23 ; 95 \% \mathrm{CI}: 1.37,7.59 ; p=0.04$ for BC-by-TL-interaction) [33], suggesting that genetic status may modify the effect of air pollution on cognitive health outcomes. The same study reported that older adults who lack an HFE C282Y variant (hemochromatosis gene polymorphisms) $(n=680$; age $71 \pm 7$ years of age) are more susceptible to the adverse effects of TRAP exposure on cognitive function [58].

\section{Discussion}

Overall, the evidence from epidemiological studies points towards an association between exposure to pollutants and cognitive health effects across the life course. There is likely adverse cognitive impact of prenatal exposure to air pollutants, such as $\mathrm{PAH}, \mathrm{NO}_{2}$, PM, POPs, with the evidence being strengthened by emerging neuroimaging research. Most studies also report an adverse cognitive impact of postnatal exposure to air pollutants in children, especially TRAP, POPs, and Isophorone. These associations have been validated by cognitive testing, neuroimaging studies and research on neuroinflammatory markers.

The largest body of research is on the cognitive impact of air pollution among the elderly population. There is robust research demonstrating dose-dependent relationships between air pollutants such as PM, black carbon, TRAP, $\mathrm{NO}_{2}$, ozone, $\mathrm{PAH}$ and cognitive performance, neuroimaging markers and incident dementia. Furthermore, research on possible aetio-pathological mechanisms indicate that some genetic factors, including $A P O$ $E$ and HFE C28y allele status, may intensify the adverse effects of air pollution on cognition, although evidence is not conclusive. 
The research on associations between air pollution and cognitive health outcomes has occurred primarily in the HICs and UMICs of Europe and North America to Asia and Latin America, whereas there is paucity of such research in the LMICs and LICs of Africa and Asia, including India. No original research has been conducted on the cognitive impact of air pollutants in LMICs or LICs, even though the air pollution is generally much higher than the World Health Organization guidelines in LMICs/LICs as compared to HICs and UMICs [71]. Even the composition of particulate ambient air pollutants differs substantially, as their sources (household, industrial, traffic, etc.) may vary by setting. For example, indoor exposure is generally higher in LICs and LMICs than in UMICs and HICs, as woodstoves are often used for cooking. The extrapolations of the doseresponse curves based on data from HICS and UMICs may not be applicable for LMICs and LICs. Therefore, generalizing results from HIC and UMICs to LICs and LMICs may be problematic due to varying levels, composition, and sources of air pollutants. The vast burden of both air pollution and neurocognitive disorders in LMICs, such as India with a $90 \%$ treatment gap [72], furthermore necessitates the synthesis of available evidence and systematic research to catalyze environmental policy change [73-75].

The proposed aetio-pathogenic pathways of air pollution's effect on cognitive decline include enhanced risk of hypertension, dyslipidemia, oxidative stress, insulin resistance, endothelial dysfunction, procoagulant states, and stroke [76,77]. The plausible aetio-pathogenic pathways furthermore include structural changes in brain, neurodegeneration, and neuroinflammation. Increased levels of $\mathrm{PM}_{2.5}$ may be associated with smaller brain volumes, white matter lesions, higher rates of infarcts, and necrotic areas in the brain, all of which contribute to cognitive impairment [78]. Pathogenic mechanisms furthermore include hypoxia and direct neurotoxicity, which results from the breakdown of nasal, gut, lung epithelial, and blood-brain barriers, allowing an influx of airborne pollutants directly into the brain $[79,80]$. Secondary neurotoxicity can also occur when cytokines are transported from a lung injury site to the brain, resulting in neuroinflammation and neurodegeneration [79,80]. Air pollution, especially $\mathrm{PM}_{2.5}$, is also associated with the enhanced expression of pro-inflammatory mediators such as tumor necrosis factor (TNF- $\alpha$ ) and interleukin-1 $\beta$ (IL-1 $\beta$ ) as well as reactive oxygen species (ROS) [81]. The summary of proposed aetio-pathogenic impact of air pollution on cognition across the life course is given in Figure 4.

The quality of individual studies incorporated in this systematic review was evaluated using the Revised tool for Quality Assessment on Diagnostic Accuracy Studies (QUADAS2) [21], and most research scored high on the quality of primary diagnostic accuracy. The risk of bias in the included studies on QUADAS-2 was low to moderate, considering that grey literature was not evaluated. The process of QUADAS-2 evaluation, by involving different researchers than the ones involved in primary screening, ensured objectivity. The studies scored low on risk of bias and applicability concerns for patient selection, index test, reference standard, flow of patients through the study, timing of the index test(s), and reference standard. This indicates that the diverse research on cognitive impact of air pollution across life course and across different income levels of sites of study is of good quality and can inform policy decisions. 


\section{Air Pollution \& Cognition Across Life Course}

\section{AIR POLLUTANTS \\ GENETIC FACTORS \\ \{Including APOE4\} \\ Sociodemographic Factors \\ \{Eduction, Age, Gender\}}

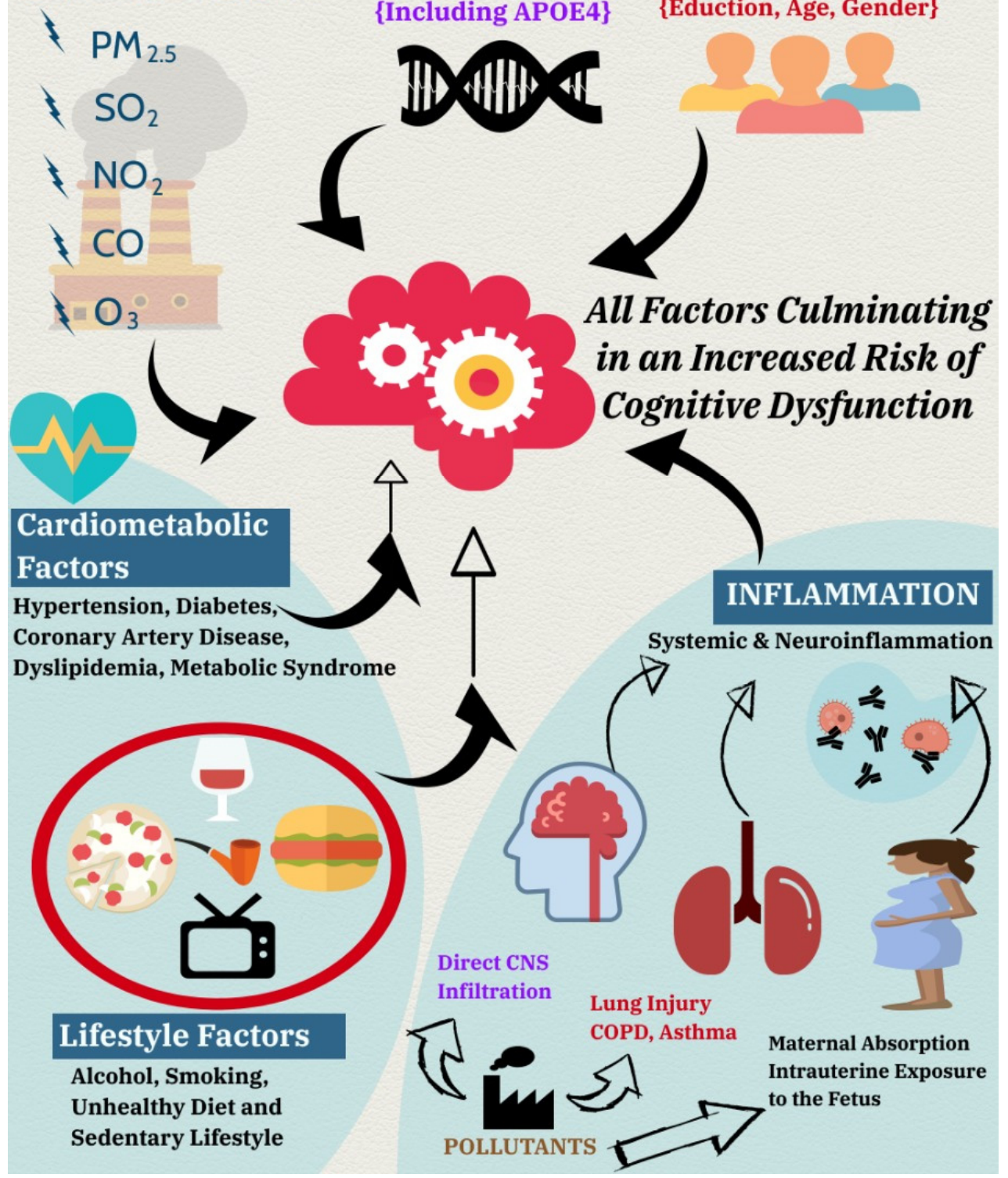

Figure 4. Proposed aetio-pathological mechanisms of cognitive impact from air pollution across the life course (made using piktochart.com).

Even though there is a growing evidence base for increasingly consistent results, dose-response relationships, and biological plausibility for air pollutants, particularly for exposure to $\mathrm{PM}_{2.5}$, the existing literature has certain limitations. The assessment of air pollution, although geocoded, may not reflect the true local exposure, as there is potential for variation even within a small geographical area. This can be further influenced by prevailing winds and seasonal patterns. Further, the individual exposure is only an estimate in these epidemiological studies and may not reflect the actual individual exposure that can be assessed in prospective studies using personal sensors. Moreover, it is a challenge to estimate and assess the effects of lifetime exposure to outdoor and indoor environmental pollutants in a mobile population, including occupational and 
transitory exposures, with complete data on exposure concentration, duration, pollutant type, and source apportionment. As the included studies utilized a variety of exposure assessment methods, such as dispersion models and land-use regression modelling, the data were too disparate to combine into a meta-analysis. Unlike cohort based epidemiological studies, case-finding bias may occur in hospital-based studies as participants may already have health concerns associated with exposure to air pollution (for example Bronchial Asthma and Chronic Obstructive Pulmonary Disease) necessitating their visit to the hospital. Adequate assessment of confounding factors, such as genetic factors (such as ApoE 64 ), cardiometabolic factors, individual and parental socioeconomic and educational status, and living conditions, is also required. Finally, there may be an emerging publication bias for studies reporting significant associations as this area expands.

This review has synthesized existing scientific evidence regarding the association between exposure to air pollution and cognitive health outcomes across the life course. However, the causal pathway of this relationship is still not fully understood, although evidence on aetio-pathogenic pathways is rapidly increasing from experimental studies. Establishing the causal effects of air pollution on cognitive health outcomes will likely require international, multicentric cohort-based research with harmonized protocols that periodically assess air pollutant exposures, cognitive function, systemic cardio-metabolic illnesses, neuroimaging, and inflammatory and genetic markers. In their 2015 systematic review of 13 studies, Peters et al. advocated for continued research on the association between air pollution and cognitive decline among older adults [81]. Additionally, two Lancet Commissions have supported emerging evidence for a causal role of PM in impaired cognition in midlife and later life, and have recommended further research [18,75]. As air pollution is a preventable risk factor, its regulation has potential health and fiscal benefits for individuals and society. Further scientific evidence (including life-course research, especially in LICs and LMICs) is required to bring about policy change for improved air quality and, thereby, protect cognition across the life course.

\section{Conclusions}

This systematic review of all published original studies on the cognitive impact of air pollution across the life course (using PRISMA guidelines) demonstrates that different air pollutants have an adverse cognitive impact across the life course. Most research is confined to HICs and UMICs with no original research in LMICs and LICS despite high rates of both air pollutants and cognitive impairment/dementia in these settings. Hence, the extrapolations of the dose-response curve based on data from HICS and UMICs may not be applicable for LMICs and LICs. As air pollution is a preventable risk factor, its regulation has potential health benefits and resultant cost-saving by potentially improving cognitive health and reducing the risk of dementia later in life. Further life-course research, especially in LICs and LMICs, is needed to establish aetio-pathogenic pathways for differential levels and cumulative exposure to air pollution, to promote policy change for air pollution and its health effects, including adverse cognitive impact.

Author Contributions: Conceptualization, M.C.; methodology, M.C.; software, C.B.R.; validation, M.C., K.C., M.K. and A.O.; formal analysis, M.C.; data curation, M.C.; writing-original draft preparation, M.C., C.B.R., N.K., V.K.S. and K.C.; writing-review and editing, M.C., K.C., M.K. and S.H.K., K.S.A. and A.O.; Visualization, M.C. and C.B.R.; Supervision and Project Administration, M.C.; funding acquisition, A.O. All authors have read and agreed to the published version of the manuscript.

Funding: This work received financial support from Swedish FORMAS under grant agreement number 2017-00898 and EU's Horizon 2020 Call: H2020-MG-2018-2019-2020 TUBE: Transport derived Ultrafines and the Brain Effects (TUBE): Project Number: 814978-2 (A. Oudin).

Acknowledgments: The authors thank Erin Flanagan for very helpful suggestions regarding language, style, and content. 
Conflicts of Interest: The authors report no conflict of interest. The funders had no role in the design of the study; in the collection, analyses, or interpretation of data; in the writing of the manuscript, or in the decision to publish the results.

\section{Abbreviations}

PM: Particulate matter, $\mathrm{PM}_{2.5}$ : Particulate matter less than 2.5 microns in diameter (fine fraction), $\mathrm{PM}_{10}$ : Particulate matter less than 10 microns in diameter, $\mathrm{PM}_{2.5-10}$ : Particulate matter between 2.5 and 10 microns in diameter (coarse fraction), HICs: High-income countries, UMICs: Upper and middle-income countries, LMICs: Low and middle-income countries, LICs: Low income countries, TNF- $\alpha$ : Tumor necrosis factor, IL-1 $\beta$ : Interleukin-1 $\beta$, ROS: Reactive oxygen species, PAH: Polyaromatic hydrocarbons, IQ: Intelligence quotient, BC: Black carbon, EC: Elemental carbon, TRAP: Traffic-related air pollution, $\mathrm{NO}_{2}$ : Nitrogen dioxide, $\mathrm{NO}_{\mathrm{x}}$ : Nitrogen oxides, $\mathrm{O}_{3}$ : ozone, $\mathrm{MMSE}$ : Mini Mental Status Examination, UFP: Ultrafine particles, POPs: Persistent organic pollutants, LD: Learning disability, CI: Confidence interval, OR: Odds ratio, HR: Hazard ratio, ASD: Autism Spectrum Disorder, ADHD: Attention Deficit Hyperactivity Disorder, GIS: Geographic information system, EPA: Environmental Protection Agency, CNS: Central nervous system, GCS: Global cognitive score, ppb: Parts per billion, WM: White matter, GM: Grey matter, MCI: Mild cognitive impairment.

\section{Appendix A}

Appendix A.1. Protocol for Systematic Review Air Pollution and Cognitive Health across the Life Course with Specific Focus on Income Level of the Study Area

A systematic review will be conducted on air pollution and cognitive health across the life course with special focus on income level of the study area as per the following protocol.

\section{Appendix A.1.1. Research Question}

What is the impact of air pollution on cognitive health across life course across diverse income settings?

\section{Appendix A.1.2. Aim and Objectives}

To study the impact of air pollution on cognitive health across life course across diverse income settings.

\section{Appendix A.1.3. Methodology}

The systematic review will be conducted in accordance with the Preferred Reporting Items for Systematic reviews and Meta-Analyses (PRISMA) statement.

The Population, Investigated Exposure, Comparison, Outcome (PICO) Framework for Research question is given in Table A1.

\section{Appendix A.2. Search Strategy}

Appendix A.2.1. Databases

PubMed database will be systematically searched for relevant literature including all articles published in English with no time limit on the date of publication.

References and citations of included papers will also be reviewed to include additional potential articles.

Abstracts of conference proceedings will be searched for any relevant papers and posters.

Grey literature will not be assessed.

Appendix A.2.2. Keywords

Studies having any of the following keywords related to cognition (outcome variable) and keywords related to pollution in their titles will be identified. These are as follows:

A. Keywords related to cognition: Dementia, Cognitive, Memory, Attention, Cognition, Concentration, Orientation, Alertness, Alert, Intelligence, Emotion (s), Language, 
Reasoning, Planning, Decision, Judgement, Recall, Learning, Insight, Processing, Visuoconstructional, Coordination, Perception,

B. Keywords related to pollution: Air Pollution, Pollutant (s), Particulate Matter, PM, Haze, Smog, Traffic-related air pollution (TRAP), Apportionment.

Table A1. Population, Investigated Exposure, Comparison, Outcome (PICO) Framework for Research question.

\begin{tabular}{|c|c|}
\hline Population & $\begin{array}{c}\text { Any Age Group } \\
\text { Both Genders } \\
\text { Participant Level Data or Cohort Level Data }\end{array}$ \\
\hline Investigated exposure & $\begin{array}{l}\text { Air Pollution: single or multiple, cross } \\
\text { sectional or cumulative exposure } \\
\text { In utero exposure, Circumscribed cross } \\
\text { sectional exposure or Lifetime exposure }\end{array}$ \\
\hline Comparison & $\begin{array}{c}\text { Air Pollutant exposed population comparators } \\
\text { Gender comparators } \\
\text { Income settings comparators }\end{array}$ \\
\hline Outcome & $\begin{array}{c}\text { Cognition and its different domains, } \\
\text { neuroimaging markers }\end{array}$ \\
\hline
\end{tabular}

\section{Appendix A.2.3. The Study Eligibility}

The study inclusion and exclusion criteria are as follows: Inclusion criteria:

- Articles will be eligible for inclusion in the review if they are full-text articles published in English with no time limit on date of publication;

- Original studies, systematic reviews, and meta-analysis will all be eligible for inclusion;

- The target population could be of any age;

- The study could have been conducted in any country/countries.

- Exclusion criteria:

- The following publications will be excluded: Protocols, Letter to editor, No full text available;

- Grey Literature will be excluded.

\section{Appendix A.3. Selecting the Studies}

Filters will be applied to restrict the results to studies published only in English and conducted using human subjects. The search results will be merged using reference management software to remove duplicate records.

The studies will be manually reviewed for relevance by three researchers independently using an eligibility checklist of our specific inclusion criteria.

\section{Appendix A.4. Data Extraction}

Search results will be imported to Zotero, where duplicates will be removed and titles screened against the eligibility criteria. All abstracts will be screened, and full-text articles accessed for screening against the eligibility criteria by two authors independently. Decisions on inclusion or exclusion will be made independently, and discrepancies will be discussed. Reference lists of included papers will also be searched to identify further studies for inclusion.

A tabulated data extraction form will be used to chart the collected data. It will contain the following items:

Study ID, study design, total study duration, population, number of participants, setting, country, details and type of exposure assessment, details of outcome variables and time points, scales, results; 
The country-level income will be determined by a nation's gross national income (GNI) per capita as High Income Countries (HICs), Upper and Middle Income Countries (UMICs), Lower and Middle Income countries (LMICS) and Lower Income Countries (LICs) as per the latest definitions given by the World Bank on its website.

\section{Appendix A.5. Data Analysis}

Data obtained will be categorized as per age group for life-course approach and income settings. If the emergent dataset is comparable in terms of predictor and outcome variables, attempts will be made to synthesize findings statistically. If the emergent dataset is heterogenous, the findings will be compared, contrasted with respect to nature of exposure, age, gender, and income settings.

\section{Appendix A.6. Quality Control}

Statistical methods for assessing publication bias using techniques such as funnel plots will be considered if the available data are amenable for such an analysis. If the emergent scientific literature is heterogenous and contains multiple exposures for multiple cognitive and neuroimaging outcomes across different age groups, the quality of individual studies will be evaluated using Quality Assessment of Diagnostic Accuracy Studies-2 (QUADAS-2) by two senior researchers independently, and any difference in agreement will be resolved by consensus with experienced researchers.

\section{Appendix A.7. Patient, Public or Stakeholder Involvement}

There will be no involvement of any patients, members of the public or stakeholders in the planning or conduct of the systematic review.

\section{Appendix B. Sites of Original Research Studies on Air Pollution and Cognition as Per Income Level of the Country}

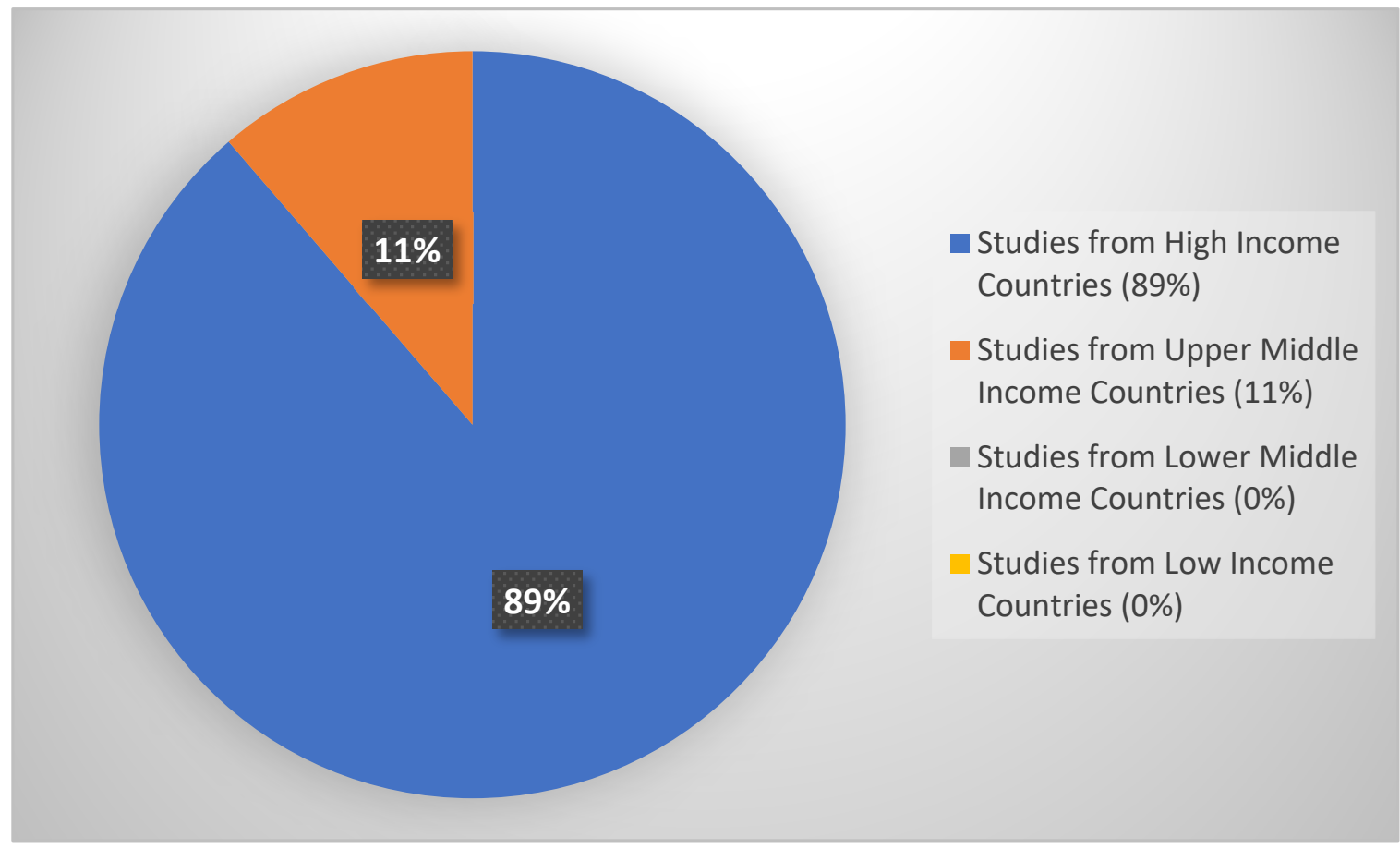

Figure A1. Original Research Studies on Air Pollution and Cognition as per World Bank Classification of the Income Level of the Country. 


\section{References}

1. Forouzanfar, M.H.; Afshin, A.; Alexander, L.T.; Anderson, H.R.; Bhutta, Z.A.; Biryukov, S. Global, regional, and national comparative risk assessment of 79 behavioural, environmental and occupational, and metabolic risks or clusters of risks, 1990-2015: A systematic analysis for the Global Burden of Disease Study 2015. Lancet 2016, 388, 1659-1724. [CrossRef]

2. $\quad$ Burnett, R.; Chen, H.; Szyszkowicz, M.; Fann, N.; Hubbell, B.; Pope, C.A.; Apte, J.S.; Brauer, M.; Cohen, A.; Weichenthal, S.; et al. Global estimates of mortality associated with long-term exposure to outdoor fine particulate matter. Proc. Natl. Acad. Sci. USA 2018, 115, 9592-9597. [CrossRef]

3. Vohra, K.; Vodonos, A.; Schwartz, J.; Marais, E.A.; Sulprizio, M.P.; Mickley, L.J. Global mortality from outdoor fine particle pollution generated by fossil fuel combustion: Results from GEOS-Chem. Environ. Res. 2021, 195, 110754. [CrossRef]

4. Babatola, S.S. Global burden of diseases attributable to air pollution. J. Public Health Afr. 2018, 9, 813. [CrossRef]

5. Abera, A.; Friberg, J.; Isaxon, C.; Jerrett, M.; Malmqvist, E.; Sjöström, C. Air Quality in Africa: Public Health Implications. Annu. Rev. Public Health 2020, 42, 193-210. [CrossRef]

6. Ostro, B.; Spadaro, J.V.; Gumy, S.; Mudu, P.; Awe, Y.; Forastiere, F.; Peters, A. Assessing the recent estimates of the global burden of disease for ambient air pollution: Methodological changes and implications for low- and middle-income countries. Environ. Res. 2018, 166, 713-725. [CrossRef]

7. Guttikunda, S.; Goel, R.; Pant, P. Nature of air pollution, emission sources, and management in the Indian cities. Atmos. Environ. 2014, 95, 501-510. [CrossRef]

8. Pal, R.; Chowdhury, S.; Dey, S.; Sharma, A.R. 18-Year Ambient PM2.5 Exposure and Night Light Trends in Indian Cities: Vulnerability Assessment. Aerosol Air Qual. Res. 2018, 18, 2332-2342. [CrossRef]

9. Naidja, L.; Ali-Khodja, H.; Khardi, S. Sources and levels of particulate matter in North African and Sub-Saharan cities: A literature review. Environ. Sci. Pollut. Res. 2018, 25, 12303-12328. [CrossRef]

10. Ferri, C.P.; Jacob, K.S. Dementia in low-income and middle-income countries: Different realities mandate tailored solutions. PLoS Med. 2017, 14, e1002271. [CrossRef] [PubMed]

11. Dementia Statistics | Alzheimer's Disease International (ADI). Available online: https://www.alzint.org/about/dementia-factsfigures/dementia-statistics/ (accessed on 3 August 2021).

12. Alvarez-Pedrerol, M.; Rivas, I.; López-Vicente, M.; Suades-González, E.; Donaire-Gonzalez, D.; Cirach, M.; de Castro, M.; Esnaola, M.; Basagaña, X.; Dadvand, P.; et al. Impact of commuting exposure to traffic-related air pollution on cognitive development in children walking to school. Environ. Pollut. 2017, 231, 837-844. [CrossRef]

13. Calderón-Garcidueñas, L.; Mora-Tiscareño, A.; Ontiveros, E.; Gómez-Garza, G.; Barragán-Mejía, G.; Broadway, J.; Chapman, S.; Valencia-Salazar, G.; Jewells, V.; Maronpot, R.R.; et al. Air pollution, cognitive deficits and brain abnormalities: A pilot study with children and dogs. Brain Cogn. 2008, 68, 117-127. [CrossRef] [PubMed]

14. Guxens, M.; Lubczyńska, M.J.; Muetzel, R.L.; Dalmau-Bueno, A.; Jaddoe, V.W.; Hoek, G.; van der Lugt, A.; Verhulst, F.C.; White, T.; Brunekreef, B.; et al. Air Pollution Exposure during Fetal Life, Brain Morphology, and Cognitive Function in School-Age Children. Biol. Psychiatry 2018, 84, 295-303. [CrossRef]

15. Cacciottolo, M.; Wang, X.; Driscoll, I.; Woodward, N.; Saffari, A.; Reyes, J.; Serre, M.L.; Vizuete, W.; Sioutas, C.; Morgan, E.T.; et al. Particulate air pollutants, APOE alleles and their contributions to cognitive impairment in older women and to amyloidogenesis in experimental models. Transl. Psychiatry 2017, 7, e1022. [CrossRef]

16. Kioumourtzoglou, M.-A.; Schwartz, J.D.; Weisskopf, M.G.; Melly, S.J.; Wang, Y.; Dominici, F.; Zanobetti, A. Long-term PM 2.5 Exposure and Neurological HospitalAdmissions in the Northeastern United States. Environ. Health Perspect. 2016, 124, 23-29. [CrossRef]

17. Power, M.C.; Adar, S.D.; Yanosky, J.D.; Weuve, J. Exposure to air pollution as a potential contributor to cognitive function, cognitive decline, brain imaging, and dementia: A systematic review of epidemiologic research. NeuroToxicology 2016, 56, 235-253. [CrossRef] [PubMed]

18. Livingston, G.; Huntley, J.; Sommerlad, A.; Ames, D.; Ballard, C.; Banerjee, S.; Brayne, C.; Burns, A.; Cohen-Mansfield, J.; Cooper, C.; et al. Dementia prevention, intervention, and care: 2020 report of the Lancet Commission. Lancet 2020, 396, 413-446. [CrossRef]

19. Moher, D.; Liberati, A.; Tetzlaff, J.; Altman, D.G.; Group, P. Preferred reporting items for systematic reviews and meta-analyses: The PRISMA statement. BMJ 2009, 339, b2535. [CrossRef] [PubMed]

20. World Bank. 2020. Available online: https://blogs.worldbank.org/opendata/new-world-bank-country-classifications-incomelevel-2020--2021 (accessed on 19 August 2020).

21. Whiting, P.F.; Rutjes, A.W.S.; Westwood, M.E.; Mallett, S.; Deeks, J.J.; Reitsma, J.B.; Leeflang, M.M.; Sterne, J.A.; Bossuyt, P.M.; QUADAS-2 Group. QUADAS-2: A Revised Tool for the Quality Assessment of Diagnostic Accuracy Studies. Ann. Intern. Med. 2011, 155, 529-536. [CrossRef] [PubMed]

22. Lee, M.; Schwartz, J.; Wang, Y.; Dominici, F.; Zanobetti, A. Long-term effect of fine particulate matter on hospitalization with dementia. Environ. Pollut. 2019, 254, 112926. [CrossRef] [PubMed]

23. Lo, Y.-T.C.; Lu, Y.-C.; Chang, Y.-H.; Kao, S.; Huang, H.-B. Air Pollution Exposure and Cognitive Function in Taiwanese Older Adults: A Repeated Measurement Study. Int. J. Environ. Res. Public Health 2019, 16, 2976. [CrossRef] [PubMed]

24. Molina-Sotomayor, E.G.O.M.; Pradas de la Fuente, F.; Carozzi Figueroa, G.S.-O.A.; González-Jurado, J.A. Effects of cardiorespiratory exercise on cognition in older women exposed to air pollution. Int. J. Environ. Res. Public Health 2019, 16, 245. [CrossRef] [PubMed] 
25. Andersson, J.; Oudin, A.; Sundström, A.; Forsberg, B.; Adolfsson, R.; Nordin, M. Road traffic noise, air pollution, and risk of dementia-results from the Betula project. Environ. Res. 2018, 166, 334-339. [CrossRef]

26. Berghuis, S.A.; Van Braeckel, K.N.; Sauer, P.J.; Bos, A.F. Prenatal exposure to persistent organic pollutants and cognition and motor performance in adolescence. Environ. Int. 2018, 121, 13-22. [CrossRef]

27. Carey, I.M.; Anderson, H.R.; Atkinson, R.W.; Beevers, S.D.; Cook, D.; Strachan, D.P.; Dajnak, D.; Gulliver, J.; Kelly, F.J. Are noise and air pollution related to the incidence of dementia? A cohort study in London, England. BMJ Open 2018, 8, e022404. [CrossRef] [PubMed]

28. Cullen, B.; Newby, D.; Lee, D.; Lyall, D.M.; Nevado-Holgado, A.J.; Evans, J.J.; Pell, J.P.; Lovestone, S.; Cavanagh, J. Cross-sectional and longitudinal analyses of outdoor air pollution exposure and cognitive function in UK Biobank. Sci. Rep. 2018, 8, 12089. [CrossRef]

29. Kerin, T.; Volk, H.; Li, W.; Lurmann, F.; Eckel, S.; McConnell, R.; Hertz-Picciotto, I. Association between Air Pollution Exposure, Cognitive and Adaptive Function, and ASD Severity among Children with Autism Spectrum Disorder. J. Autism Dev. Disord. 2017, 48, 137-150. [CrossRef]

30. Oudin, A.; Segersson, D.; Adolfsson, R.; Forsberg, B. Association between air pollution from residential wood burning and dementia incidence in a longitudinal study in Northern Sweden. PLoS ONE 2018, 13, e0198283. [CrossRef]

31. Ailshire, J.; Karraker, A.; Clarke, P. Neighborhood social stressors, fine particulate matter air pollution, and cognitive function among older US adults. Soc. Sci. Med. 2017, 172, 56-63. [CrossRef]

32. Chen, H.; Kwong, J.C.; Copes, R.; Hystad, P.; van Donkelaar, A.; Tu, K.; Brook, J.R.; Goldberg, M.S.; Martin, R.V.; Murray, B.; et al. Exposure to ambient air pollution and the incidence of dementia: A population-based cohort study. Environ. Int. 2017, 108, 271-277. [CrossRef]

33. Colicino, E.; Wilson, A.; Frisardi, M.C.; Prada, D.; Power, M.C.; Hoxha, M.; Dioni, L.; Spiro, A.; Vokonas, P.S.; Weisskopf, M.G.; et al. Telomere Length, Long-Term Black Carbon Exposure, and Cognitive Function in a Cohort of Older Men: The VA Normative Aging Study. Environ. Health Perspect. 2017, 125, 76-81. [CrossRef] [PubMed]

34. Forns, J.; Dadvand, P.; Esnaola, M.; Alvarez-Pedrerol, M.; López-Vicente, M.; Garcia-Esteban, R.; Cirach, M.; Basagaña, X.; Guxens, M.; Sunyer, J. Longitudinal association between air pollution exposure at school and cognitive development in school children over a period of 3.5 years. Environ. Res. 2017, 159, 416-421. [CrossRef]

35. Lett, E.; Stingone, J.A.; Claudio, L. The Combined Influence of Air Pollution and Home Learning Environment on Early Cognitive Skills in Children. Int. J. Environ. Res. Public Health 2017, 14, 1295. [CrossRef]

36. Oudin, A.; Forsberg, B.; Lind, N.; Nordin, S.; Åström, D.O.; Sundström, A. Is long-term exposure to air pollution associated with episodic memory? A longitudinal study from Northern Sweden. Sci. Rep. 2017, 7, 12789. [CrossRef]

37. Stingone, J.A.; Pandey, O.P.; Claudio, L.; Pandey, G. Using machine learning to identify air pollution exposure profiles associated with early cognitive skills among U.S. children. Environ. Pollut. 2017, 230, 730-740. [CrossRef]

38. Sunyer, J.; Suades-González, E.; García-Esteban, R.; Rivas, I.; Pujol, J.; Alvarez-Pedrerol, M. Traffic-related air pollution and attention in primary school children: Short-term association. Epidemiology 2017, 28, 181. [CrossRef] [PubMed]

39. Tallon, L.A.; Manjourides, J.; Pun, V.C.; Salhi, C.; Suh, H. Cognitive impacts of ambient air pollution in the National Social Health and Aging Project (NSHAP) cohort. Environ. Int. 2017, 104, 102-109. [CrossRef]

40. Tzivian, L.; Jokisch, M.; Winkler, A.; Weimar, C.; Hennig, F.; Sugiri, D.; Soppa, V.J.; Dragano, N.; Erbel, R.; Jöckel, K.-H.; et al. Associations of long-term exposure to air pollution and road traffic noise with cognitive function-An analysis of effect measure modification. Environ. Int. 2017, 103, 30-38. [CrossRef] [PubMed]

41. Best, E.A.; Juarez-Colunga, E.; James, K.; Leblanc, W.G.; Serdar, B. Biomarkers of Exposure to Polycyclic Aromatic Hydrocarbons and Cognitive Function among Elderly in the United States (National Health and Nutrition Examination Survey: 2001-2002). PLoS ONE 2016, 11, e0147632. [CrossRef]

42. Oudin, A.; Forsberg, B.; Adolfsson, A.N.; Lind, N.; Modig, L.; Nordin, M.; Nordin, S.; Adolfsson, R.; Nilsson, L.-G. Traffic-Related Air Pollution and Dementia Incidence in Northern Sweden: A Longitudinal Study. Environ. Health Perspect. 2016, 124, 306-312. [CrossRef]

43. Porta, D.; Narduzzi, S.; Badaloni, C.; Bucci, S.; Cesaroni, G.; Colelli, V.; Davoli, M.; Sunyer, J.; Zirro, E.; Schwartz, J.; et al. Air pollution and cognitive development at age seven in a prospective Italian birth cohort. Epidemiology 2015, 27, 228-236. [CrossRef]

44. Tzivian, L.; Dlugaj, M.; Winkler, A.; Hennig, F.; Fuks, K.; Sugiri, D.; Schikowski, T.; Jakobs, H.; Erbel, R.; Jöckel, K.-H.; et al. Long-term air pollution and traffic noise exposures and cognitive function: A cross-sectional analysis of the Heinz Nixdorf Recall study. J. Toxicol. Environ. Health Part A 2016, 79, 1057-1069. [CrossRef]

45. Tzivian, L.; Dlugaj, M.; Winkler, A.; Weinmayr, G.; Hennig, F.; Fuks, K.B.; Vossoughi, M.; Schikowski, T.; Weimar, C.; Erbel, R.; et al. Long-Term Air Pollution and Traffic Noise Exposures and Mild Cognitive Impairment in Older Adults: A Cross-Sectional Analysis of the Heinz Nixdorf Recall Study. Environ. Health Perspect. 2016, 124, 1361-1368. [CrossRef] [PubMed]

46. Chen, J.-C.; Wang, X.; ScD, G.A.W.; Serre, M.; Driscoll, I.; Casanova, R.; McArdle, J.J.; Manson, J.E.; Chui, H.C.; Espeland, M.A. Ambient air pollution and neurotoxicity on brain structure: Evidence from women's health initiative memory study. Ann. Neurol. 2015, 78, 466-476. [CrossRef]

47. Harris, M.H.; Gold, D.R.; Rifas-Shiman, S.L.; Melly, S.J.; Zanobetti, A.; Coull, B.A.; Schwartz, J.D.; Gryparis, A.; Kloog, I.; Koutrakis, P.; et al. Prenatal and Childhood Traffic-Related Pollution Exposure and Childhood Cognition in the Project Viva Cohort (Massachusetts, USA). Environ. Health Perspect. 2015, 123, 1072-1078. [CrossRef] 
48. Peterson, B.S.; Rauh, V.A.; Bansal, R.; Hao, X.; Toth, Z.; Nati, G.; Walsh, K.; Miller, R.L.; Arias, F.; Semanek, D.; et al. Effects of Prenatal Exposure to Air Pollutants (Polycyclic Aromatic Hydrocarbons) on the Development of Brain White Matter, Cognition, and Behavior in Later Childhood. JAMA Psychiatry 2015, 72, 531-540. [CrossRef] [PubMed]

49. Schikowski, T.; Vossoughi, M.; Vierkötter, A.; Schulte, T.; Teichert, T.; Sugiri, D.; Fehsel, K.; Tzivian, L.; Bae, I.-S.; Ranft, U.; et al. Association of air pollution with cognitive functions and its modification by APOE gene variants in elderly women. Environ. Res. 2015, 142, 10-16. [CrossRef]

50. Sunyer, J.; Esnaola, M.; Alvarez-Pedrerol, M.; Forns, J.; Rivas, I.; López-Vicente, M.; Suades-González, E.; Foraster, M.; GarciaEsteban, R.; Basagaña, X.; et al. Association between Traffic-Related Air Pollution in Schools and Cognitive Development in Primary School Children: A Prospective Cohort Study. PLoS Med. 2015, 12, e1001792. [CrossRef]

51. Ailshire, J.A.; Clarke, P. Fine Particulate Matter Air Pollution and Cognitive Function among U.S. Older Adults. J. Gerontol. Ser. B 2014, 70, 322-328. [CrossRef] [PubMed]

52. Jennifer, A.; Ailshire, E.M.C. Fine particulate matter air pollution and cognitive function among older US adults. Am. J. Epidemiol. 2014, 180, 359-366.

53. Gatto, N.M.; Henderson, V.W.; Hodis, H.N.; John, J.A.S.; Lurmann, F.; Chen, J.-C.; Mack, W.J. Components of air pollution and cognitive function in middle-aged and older adults in Los Angeles. NeuroToxicology 2013, 40, 1-7. [CrossRef]

54. Guxens, M.; Garcia-Esteban, R.; Giorgis-Allemand, L.; Forns, J.; Badaloni, C.; Ballester, F. Air Pollution during Pregnancy and Childhood Cognitive and Psychomotor Development: Six European Birth Cohorts. Epidemiology 2014, 25, 636-647. [CrossRef]

55. Tonne, C.; Elbaz, A.; Beevers, S.; Singh-Manoux, A. Traffic-related Air Pollution in Relation to Cognitive Function in Older Adults. Epidemiology 2014, 25, 674-681. [CrossRef]

56. Loop, M.S.; Kent, S.T.; Al-Hamdan, M.Z.; Crosson, W.L.; Estes, S.M.; Estes, M.G., Jr. Fine particulate matter and incident cognitive impairment in the REasons for Geographic and Racial Differences in Stroke (REGARDS) cohort. PLoS ONE 2013,8 , e75001. [CrossRef]

57. Power, M.C.; Weisskopf, M.G.; Alexeeff, E.S.; Wright, R.; Coull, A.B.; Spiro, A.; Schwartz, J. Modification by hemochromatosis gene polymorphisms of the association between traffic-related air pollution and cognition in older men: A cohort study. Environ. Health 2013, 12, 16. [CrossRef] [PubMed]

58. Weuve, J.; Puett, R.C.; Schwartz, J.; Yanosky, J.D.; Laden, F.; Grodstein, F. Exposure to Particulate Air Pollution and Cognitive Decline in Older Women. Arch. Intern. Med. 2012, 172, 219-227. [CrossRef] [PubMed]

59. Power, M.C.; Weisskopf, M.G.; Alexeeff, S.E.; Coull, B.A.; Spin, A., III; Schwartz, J. Traffic-related air pollution and cognitive function in a cohort of older men. Environ. Health Perspect. 2011, 119, 682. [CrossRef] [PubMed]

60. Edwards, S.C.; Jedrychowski, W.; Butscher, M.; Camann, D.; Kieltyka, A.; Mroz, E.; Flak, E.; Li, Z.; Wang, S.; Rauh, V.; et al. Prenatal Exposure to Airborne Polycyclic Aromatic Hydrocarbons and Children's Intelligence at 5 Years of Age in a Prospective Cohort Study in Poland. Environ. Health Perspect. 2010, 118, 1326-1331. [CrossRef]

61. Freire, C.; Ramos, R.; Puertas, R.; Lopez-Espinosa, M.-J.; Julvez, J.; Aguilera, I.; Cruz, F.; Fernandez, M.-F.; Sunyer, J.; Olea, N. Association of traffic-related air pollution with cognitive development in children. J. Epidemiol. Commun. Health 2009, 64, 223-228. [CrossRef]

62. Chen, J.-C.; Schwartz, J. Neurobehavioral effects of ambient air pollution on cognitive performance in US adults. NeuroToxicology 2009, 30, 231-239. [CrossRef]

63. Perera, F.P.; Li, Z.; Whyatt, R.; Hoepner, L.; Wang, S.; Camann, D.; Rauh, V. Prenatal Airborne Polycyclic Aromatic Hydrocarbon Exposure and Child IQ at Age 5 Years. Pediatrics 2009, 124, e195-e202. [CrossRef]

64. Ranft, U.; Schikowski, T.; Sugiri, D.; Krutmann, J.; Krämer, U. Long-term exposure to traffic-related particulate matter impairs cognitive function in the elderly. Environ. Res. 2009, 109, 1004-1011. [CrossRef]

65. Lee, D.-H.; Jacobs, D.R.; Porta, M. Association of serum concentrations of persistent organic pollutants with the prevalence of learning disability and attention deficit disorder. J. Epidemiol. Commun. Health 2007, 61, 591-596. [CrossRef] [PubMed]

66. Saenz, J.L.; Wong, R.; A Ailshire, J. Indoor air pollution and cognitive function among older Mexican adults. J. Epidemiol. Commun. Health 2017, 72, 21-26. [CrossRef]

67. Zhang, X.; Chen, X.; Zhang, X. The impact of exposure to air pollution on cognitive performance. Proc. Natl. Acad. Sci. USA 2018, 115, 9193-9197. [CrossRef]

68. Calderón-Garcidueñas, L.; Kavanaugh, M.; Block, M.; D’Angiulli, A.; Delgado-Chávez, R.; Torres-Jardón, R.; González-Maciel, A.; Reynoso-Robles, R.; Osnaya, N.; Villarreal-Calderon, R.; et al. Neuroinflammation, Hyperphosphorylated Tau, Diffuse Amyloid Plaques, and Down-Regulation of the Cellular Prion Protein in Air Pollution Exposed Children and Young Adults. J. Alzheimer Dis. 2012, 28, 93-107. [CrossRef] [PubMed]

69. Calderón-Garcidueñas, L.; Engle, R.; Mora-Tiscareño, A.; Styner, M.; Gómez-Garza, G.; Zhu, H.; Jewells, V.; Torres-Jardón, R.; Romero, L.; Monroy-Acosta, M.E.; et al. Exposure to severe urban air pollution influences cognitive outcomes, brain volume and systemic inflammation in clinically healthy children. Brain Cogn. 2011, 77, 345-355. [CrossRef]

70. Wang, J.N.; Wang, Q.; Li, T.T.; Shi, X.M. Association between air pollution and cognitive function in the elderly. Chin. J. Prev. Med. 2017, 51, 364-368. (In Chinese)

71. Sharma, S.; Chandra, M.; Kota, S.H. Health Effects Associated with PM2.5: A Systematic Review. Curr. Pollut. Rep. 2020, 6, 345-367. [CrossRef]

72. Dias, A.; Patel, V. Closing the treatment gap for dementia in India. Indian J. Psychiatry 2009, 51, S93-S97. 
73. Prince, M.J. World Alzheimer Report 2015: The Global Impact of Dementia: An Analysis of Prevalence, Incidence, Cost and Trends; Alzheimer's Disease International: London, UK, 2015.

74. Shaji, K.S.; Jithu, V.P.; Jyothi, K.S. Indian research on aging and dementia. Indian J. Psychiatry 2010, 52, 148-152. [CrossRef]

75. Landrigan, P.J.; Fuller, R.; Acosta, N.J.R.; Adeyi, O.; Arnold, R.; Basu, N.; Baldé, A.B.; Bertollini, R.; Bose-O’Reilly, S.; Boufford, J.I.; et al. The Lancet Commission on pollution and health. Lancet 2018, 391, 462-512. [CrossRef]

76. Shah, A.S.V.; Lee, K.K.; McAllister, D.; Hunter, A.; Nair, H.; Whiteley, W.; Langrish, J.P.; E Newby, D.; Mills, N. Short term exposure to air pollution and stroke: Systematic review and meta-analysis. BMJ 2015, 350, h1295. [CrossRef]

77. Chen, X. Smog, cognition and real-world decision-making. Int. J. Health Policy Manag. 2019, 8, 76. [CrossRef] [PubMed]

78. Schraufnagel, D.E.; Balmes, J.R.; Cowl, C.T.; De Matteis, S.; Jung, S.-H.; Mortimer, K. Air pollution and noncommunicable diseases: A review by the Forum of International Respiratory Societies' Environmental Committee, Part 2: Air pollution and organ systems. Chest 2019, 155, 417-426. [CrossRef] [PubMed]

79. Block, M.L.; Calderón-Garcidueñas, L. Air pollution: Mechanisms of neuroinflammation and CNS disease. Trends Neurosci. 2009, 32, 506-516. [CrossRef] [PubMed]

80. Li, J.; Liu, Y.; An, Z.; Li, W.; Zeng, X.; Li, H.; Jiang, J.; Song, J.; Wu, W. Seasonal Variations in PM2.5-induced Oxidative Stress and Up-regulation of Pro-inflammatory Mediators. Aerosol Air Qual. Res. 2020, 20, 679-687. [CrossRef]

81. Peters, R.; Peters, J.; Booth, A.; Mudway, I. Is air pollution associated with increased risk of cognitive decline? A systematic review. Age Ageing 2015, 44, 755-760. [CrossRef] [PubMed] 